\title{
Grazing control of phytoplankton stock in the open subarctic Pacific Ocean: a model assessing the role of mesozooplankton, particularly the large calanoid copepods Neocalanus spp.
}

\author{
B. W. Frost \\ School of Oceanography, WB-10, University of Washington, Seattle, Washington 98195, USA
}

\begin{abstract}
An ecosystem process model is developed and used to probe the hypothesis that grazing by zooplankton controls the standing stock of phytoplankton at Station $\mathrm{P}\left(50^{\circ} \mathrm{N}, 145^{\circ} \mathrm{W}\right)$ in the eastern subarctic Pacific Ocean. The model attempts to reproduce seasonal variations and integrated interactions of specific physical, chemical, and biological components of the subarctic pelagic ecosystem, and to simulate quantitatively the observed level of phytoplankton production. In its various versions the model describes the annual cycle of standing stock and production of phytoplankton, herbivorous microzooplankton, and the concentration of dissolved inorganic nitrogenous nutrients in a homogeneous mixed layer. Mesozooplankton (which include the large suspension-feeding copepods Neocalanus spp.) are assessed for their potential as dominant grazers of phytoplankton and, alternatively, as omnivorous consumers of phytoplankton and herbivorous microzooplankton. This model indicates that a hypothesized trophic structure, in which herbivorous microzooplankton are the major grazers of phytoplankton and mesozooplankton are indiscriminate omnivores, is plausible in theory and consistent with available but limited observations.
\end{abstract}

\section{INTRODUCTION}

Oceanic waters of the subarctic Pacific Ocean provide an important test-case for our understanding of processes controlling the production and utilization of organic matter in the surface layer. It is a welldocumented phenomenon, particularly in the Gulf of Alaska at Ocean Station P $\left(50^{\circ} \mathrm{N}, 145^{\circ} \mathrm{W}\right)$, that phytoplankton stock (measured as chlorophyll a) shows no discernable seasonal cycle (Frost et al. 1983) despite substantial seasonal change in phytoplankton production rate (McAllister 1969). Parsons \& LeBrasseur (1968) suggested that positive net production of phytoplankton might be possible at Station P even before the formation of the seasonal thermocline in late April or early May because the shallow permanent halocline limits winter mixing to the upper 100 to $130 \mathrm{~m}$. Moreover, they noted that from May or June to September the mixed layer depth is much less than the critical depth. Yet concentrations of macronutrients are continuously very high at Station P (Anderson et al. 1969, 1977) and phytoplankton stock remains low. The lack of seasonal change in phytoplankton stock, particularly in summer when environmental conditions (light, macronutrients) definitely appear favorable to phytoplankton growth, has led to the notion that phytoplankton net production is continuously removed by planktonic grazers, thus maintaining a steady standing stock of phytoplankton (McAllister et al. 1960, Parsons $\&$ LeBrasseur 1968). Though not as intensively studied outside the Gulf of Alaska, the phenomenon seems to apply throughout the open subarctic Pacific, including the waters over the deep basin in the Bering Sea (Heinrich 1962, Parsons \& Anderson 1970, Larrance 1971, Anderson \& Munson 1972, Saino et al. 1979).

Most interpretations of the dynamics of phytoplankton stock and production have been qualitative, merely inferring circumstantially that there must be a balance between growth of phytoplankton and grazing by zooplankton. Parsons' (1965, p. 26) calculations indicated, however, that there could indeed be approximate balance between phytoplankton growth and zooplankton grazing at Station P during the summer, but he did not specifically identify the grazers, nor did he discuss 
the mechanism by which grazers could maintain constant biomass of phytoplankton. Moreover, the consumption rate that he assumed for the grazing zooplankton would require them to have extraordinary foraging capabilities, given the low ambient phytoplankton concentrations.

Heinrich (1957, 1962) and Beklemishev (1957) suggested that 2 endemic species of large calanoid copepods, Neocalanus cristatus and $N$. plumchrus, are the major grazers of phytoplankton in the open subarctic Pacific. A third oceanic subarctic Pacific species of Neocalanus was recently discovered (C. B. Miller pers. comm.). Neocalanus spp. are dominant components of the mesozooplankton (sensu Sieburth et al. 1978) during much of the year and they have feeding behaviors (Frost et al. 1983) and life history patterns (Miller et al. 1984, C. B. Miller pers. comm.) that are consistent with their presumed role as major grazers. However, it still remains to be shown experimentally that the species of Neocalanus can exert grazing pressure sufficient to continuously control phytoplankton stock. In addition, the 3 species of Neocalanus make ontogenetic migrations into deep water in succession from late spring to late summer at Station P (Miller et al. 1984, C. B. Miller pers. comm.), leaving the mixed layer uninhabited by Neocalanus for about 2 mo in late summer and autumn. Clearly, some alternative control of phytoplankton stock must be operating at least when the species of Neocalanus are in deep water. Evans \& Parslow (1985) suggested that Neocalanus species may play a role as grazers subsidiary to that of an unspecified assemblage of 'other herbivores which reproduce more or less continuously'.

The purpose of this paper is to thoroughly explore, by means of a mathematical model, the plausibility of the grazing hypothesis as an explanation of the annual cycle of standing stock and production of phytoplankton in open waters in the subarctic Pacific. The objective is to put sensible constraints on the possible mechanisms of control based on current knowledge of processes affecting growth of phytoplankton and grazing by zooplankton. This is an extension of previous modelling efforts relevant to the subarctic Pacific (McAllister 1969, 1970, Anderson et al. 1977, Parslow 1981).
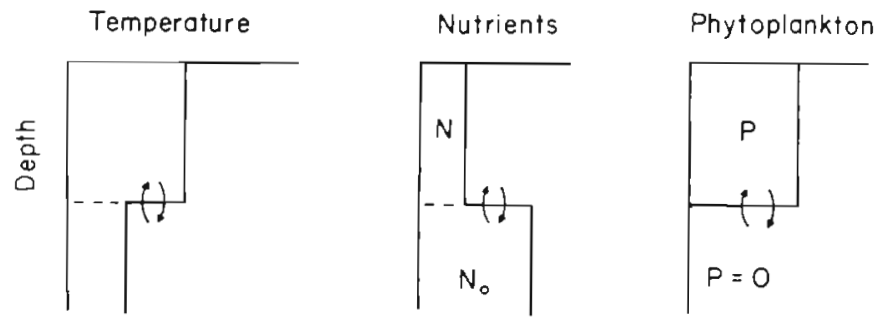

An ecosystem model, combining features of Riley's (1963) and Steele's (1974) madels, was developed to simulate the annual cycle of plankton production at Ocean Station P. The model attempts to reproduce seasonal variations and integrated interactions of specific physical, chemical, and biological components of the subarctic pelagic ecosystem, and attempts to reproduce quantitatively the observed levels of biological production. Nevertheless, following the admonitions of Platt et al. (1981) and Evans \& Parslow (1985), the model has been kept as simple as possible to facilitate its interpretation.

\section{AN ECOSYSTEM MODEL - STRUCTURE AND RATIONALE}

\section{Physical structure}

The model described seasonal variation of phytoplankton stock and production at a point in the ocean, taken to be Station P. Horizontal advection and diffusion were ignored. Following Steele (1974), the pelagic ecosystem was assumed to consist of a homogeneously mixed upper layer and a deeper layer. At Station P the two are separated in winter by the permanent halocline which effectively limits the winter mixed layer to a depth of only about 100 to $130 \mathrm{~m}$ (Dodimead et al. 1963). At other times the boundary between the 2 layers is a shallower thermocline whose depth varies seasonally. It was assumed that phytoplankton are confined to and homogeneously distributed in the upper layer. A constant fraction, $v$, of the upper mixed layer was exchanged each day with the lower layer, bringing nutrients into the mixed layer and removing phytoplankton (Fig. 1).

Restricting the phytoplankton to the mixed layer was an oversimplification, but eliminated the need for detailed parameterization of mixing and phytoplankton growth and grazing mortality within the pycnocline. When the seasonal thermocline is present, and especially in summer, a substantial amount of chlorophyll a can occur below the mixed layer at Station P (Anderson et al. 1977); significant phytoplankton production can also occur below the mixed layer at

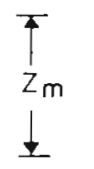

Fig. 1. Vertical structure used in the model. When present, the seasonal thermocline determined the depth of the mixed layer $\left(z_{m}\right)$, in winter $z_{m}$ extencled to the top of the permanent halocline. Small arrows indicate exchange between the mixed layer and the deeper layer, a process parameterized in the model by the mixing coefficient 
these times (C. J. Lorenzen pers. comm.). Thus, model estimates of phytoplankton production in the mixed layer will at times be underestimates of integrated water column primary production at Station P. This is not considered a limitation since phytoplankton growth in the mixed layer sets definite lower bounds on the required capacity of the grazers if they are to control the stock of phytoplankton. If grazing cannot balance phytoplankton growth in the mixed layer, where conditions for phytoplankton growth are most favorable, it makes no difference what happens below.

In general, phytoplankton are uniformly distributed in the mixed layer at Station $\mathrm{P}$ and there is no subsurface maximum (Anderson et al. 1977); that is, the mixed layer appears homogeneously mixed. Horizontal variation in phytoplankton stock exists in the vicinity of Station P (McAllister et al. 1960, Parsons \& Anderson 1970, Mackas pers. comm.), but on scales of 10 to $20 \mathrm{~km}$ the range of variation is relatively small $(<0.6$ mg chlorophyll $\mathrm{a} \mathrm{m}^{-3}$ ). In quasi-synoptic spatial surveys phytoplankton stocks in bloom concentrations (>2 mg chlorophyll a $\mathrm{m}^{-3}$ ) have not been observed within several hundred kilometers of Station $P$, suggesting that the control of phytoplankton stock is not a phenomenon peculiar to that locality, but pertains everywhere throughout open waters of the eastern subarctic Pacific (Parsons \& Anderson 1970, Anderson \& Munson 1972, Anderson et al. 1977).
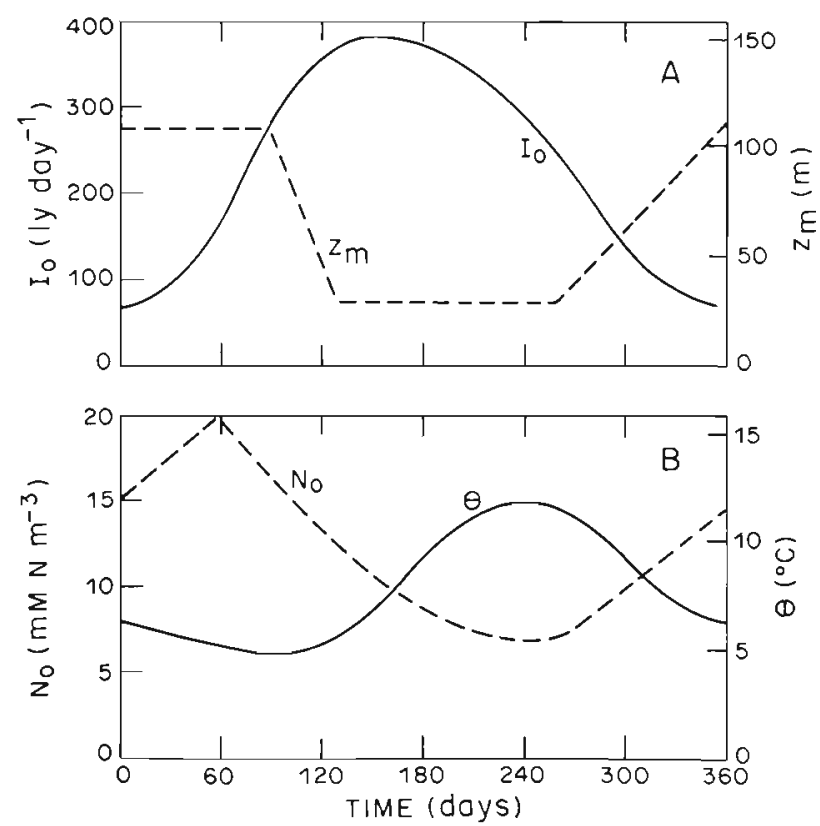

Fig. 2. Environmental variables serving as input to the model. (A) Total incident solar radiation $\left(I_{0}\right)$ and depth of the mixed layer $\left(z_{m}\right)$. (B) Mixed layer temperature $(\theta)$ and nutrient (nitrate) concentration $\left(N_{0}\right)$ below the mixed layer. Curve for $N_{0}$ was obtained by superimposing $z_{m}$ on Fig. $4 \mathrm{C}$
It was assumed that the major physical environmental variables affecting production rate of the phytoplankton in the mixed layer were incident solar radiation, the mixed layer depth, mixed layer temperature, and attenuation of light in the mixed layer. Data on these variables were based on averages of observations made at Station P. The sources of the data and their representation in the model are next described.

\section{Incident solar radiation and irradiance in the mixed layer}

Mean monthly values of total solar radiation, measured with an Eppley pyrheliometer and reported in units of ly $\mathrm{d}^{-1}$, are available from Anderson et al. (1977). These data (Fig. 2A) may be converted to photosynthetically active photon flux (Bannister 1974); specifically, 1 ly $\mathrm{d}^{-1}$ of total solar radiation, as measured by the pyrheliometer, is approximatively equivalent to $8.3 \times 10^{-2} \mathrm{E} \mathrm{m}^{-2} \mathrm{~d}^{-1}$ of visible light.

At any depth $z$ in the mixed layer the daily irradiance, $I_{z}$ was calculated as

$$
\mathrm{I}_{\mathrm{z}}=\mathrm{I}_{0} \mathrm{e}^{-\mathrm{kz}}
$$

where $\mathrm{I}_{0}=$ daily incident solar radiation; $\mathrm{z}$ is in meters; and $\mathrm{k}=$ the attenuation coefficient for irradiance in the mixed layer. The coefficient $\mathrm{k}$ depended on the concentration of phytoplankton as well as absorption by the water:

$$
\mathrm{k}=\mathrm{aP}^{*}+\mathrm{b}
$$

where the units of $\mathrm{k}$ are $\mathrm{m}^{-1} ; \mathrm{P}^{*}=$ concentration of chlorophyll $a\left(\mathrm{mg} \mathrm{m}^{-3}\right)$ in the mixed layer; and a and $\mathrm{b}$ $=$ constants. Parameter a was $0.02 \mathrm{~m}^{2} \mathrm{mg}^{-1}$ (Parsons et al. 1984) and if $b=0.1 \mathrm{~m}^{-1}$ the computed values of $\mathrm{k}$ were in the range of seasonal variation observed at Station P (Parsons et al. 1966). Half the daily irradiance at any depth $z$ in the mixed layer (in units ly $d^{-1}$ ) was taken to be photosynthetically active radiation $(\mathrm{PARz}=$ $\left.0.5 \mathbf{I}_{\mathbf{z}}\right)$.

\section{Mixed layer depth and temperature in the mixed layer}

Seasonal variation in mixed layer depth (Fig. 2A) was based on a fit to the mean monthly observations at Station P (Parsons et al. 1966). This is clearly an oversimplification, neglecting day-to-day variation in mixing due to calm spells and storms, diel cycles of heating and cooling in summer (Davis et al. 1981), and year-toyear variation in time of formation of the seasonal thermocline in spring (Parsons \& LeBrasseur 1968). The likely effect of this simplification is to underestimate phytoplankton production rate in an unknown way. Mean monthly values of mixed layer temperature 
(Dodimead et al. 1963) were used to construct a continuous curve of daily mean temperature (Fig. 2B).

\section{Phytoplankton}

In the absence of physiological investigations on phytoplankton species inhabiting the open subarctic Pacific, phytoplankton are represented in the model as a single functional group with physiological characteristics elaborated in sections below. Although a long time series is available on the annual cycle of abundance of phytoplankton (estimated as concentration of chlorophyll a) at Station $P$, the specific composition of the phytoplankton is less well known. In late spring and summer phytoplankton are predominantly nanoplankton-sized cells, with most of the biomass (>70\%) composed of cells < $10 \mu \mathrm{m}$ (McAllister et al. 1960, Booth in press). In May and August 1984, Booth (in press) found a diverse assemblage of nanoplankton, including Synechococcus spp., flagellates, non-motile coccoids, dinoflagellates, cryptomonads, and diatoms. The
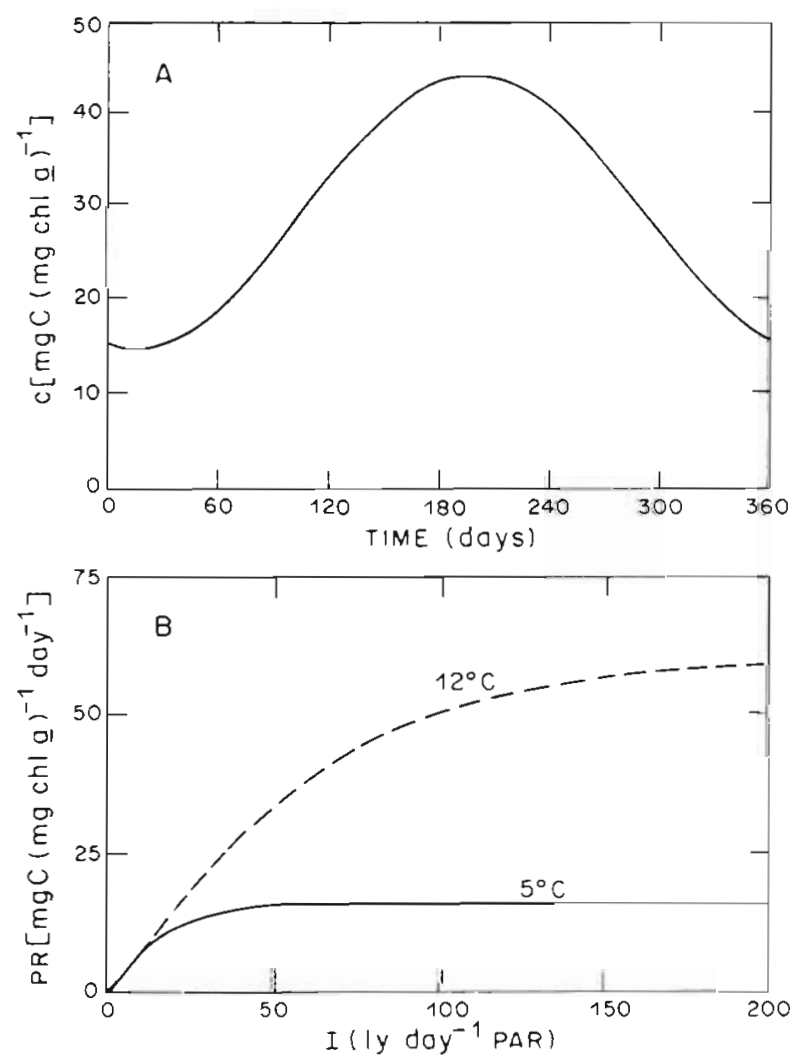

Fig. 3. (A) Seasonal variation in carbon-to-chlorophyll a ratio (c); the pattern of variation, adapted from McAllister (1969), follows $c=30-15 \cos [2 \pi(T-15) / 365]$ where $T$ is day of the year. (B) Chlorophyll a-specific photosynthetic rate (PR) as a function of photosynthetically active radiation (I) and temperature abundance of some species of microphytoplankton (cells $>20 \mu \mathrm{m}$ ) may vary substantially, but their concentrations are so low as to cause negligible changes in phytoplankton biomass (e.g. Clemons \& Miller 1984). Thus, for example, there is no evidence of seasonal or shorter-term shifts between flagellate-dominated and diatom-dominated assemblages.

\section{Concentration of chlorophyll $a$ in the mixed layer}

The model described phytoplankton production rate in terms of carbon, but the concentration of chlorophyll a was needed, not only for the calculation of attenuation coefficient for irradiance and the relationship of photosynthesis to irradiance, but also to describe the stock of phytoplankton in readily observable units. Phytoplankton stock, as $\mathrm{mgC}^{-3}(\mathrm{P})$ was related to concentration of chlorophyll a $\left(\mathrm{P}^{*}\right)$ by

$$
\mathrm{P}=\mathrm{CP}^{\cdot}
$$

where $\mathrm{c}=$ carbon-to-chlorophyll a ratio of phytoplankton. The ratio $c$ varied seasonally between 15 and 45 mgC ( $\mathrm{mg} \mathrm{chl} \mathrm{a)})^{-1}$ according to the pattern (Fig. 3A) suggested by McAllister (1969). However, because this possibly underestimates $\mathrm{c}$ for the phytoplankton at Station P (Parslow 1981), I also looked at the effect of systematically increasing $\mathrm{c}$.

\section{Photosynthetic rate of phytoplankton}

In the model the photosynthetic rate of the phytoplankton depended on both light and nutrients. At any depth $z$ in the mixed layer the chlorophyll a-specific photosynthetic rate was taken as

$\operatorname{mgC}(\operatorname{mgchl} a)^{-1} \mathrm{~d}^{-1}=\mathrm{PMAX} \cdot \tanh \left(\alpha \mathrm{PAR}_{\mathrm{z}} / \mathrm{PMAX}^{*}\right)(4)$

where $\alpha=$ photosynthetic efficiency $\left[\mathrm{mgC}(\mathrm{mg} \mathrm{chl} a)^{-1}\right.$ $\left.1 y^{-1}\right]$, specifying the initial slope of the photosynthesis versus irradiance curve (Jassby \& Platt 1976). PMAX * was derived from PMAX, the maximum finite, daily mass-specific growth rate $\left(\mathrm{d}^{-1}\right)$ as follows. The temperature dependency for doubling rate of phytoplankton was determined by Eppley (1972):

$$
\mathrm{D}=\text { doublings } \mathrm{d}^{-1}=0.851(10)^{0.02750}
$$

where $\theta=$ temperature $\left({ }^{\circ} \mathrm{C}\right)$. Since the relation was established for laboratory cultures, most of which were exposed to continuous light, then adjusting for number of hours of daylight (DL), PMAX was related to D by

$$
\mathrm{PMAX}=\left(\mathrm{e}^{\operatorname{Din} 2}-1.0\right) \mathrm{DL} / 24
$$

where DL for any day of the year $T$ was approximated by 


$$
\mathrm{DL}=12.38-4.13 \cos [2 \pi(\mathrm{T}+10) / 365]
$$

This expression for DL gives a close approximation of daylight at $50^{\circ} \mathrm{N}$ based on astronomical data (Brock 1981). The maximum, chlorophyll a-specific, growth rate, PMAX', was calculated as

$$
\mathrm{PMAX}^{*}=\mathrm{CPMAX}^{-}
$$

Over the seasonal range of mixed layer temperature (5.0 to $12.0^{\circ} \mathrm{C}$; Fig. 2B) PMAX varied from 17.5 to 60.9 $\mathrm{mgC}$ ( $\mathrm{mg} \mathrm{chl} \mathrm{a})^{-1} \mathrm{~d}^{-1}$ in the model. These values bracket the estimates of PMAX ' obtained in May and August 1984 at Station P (M. J. Perry pers. comm.).

Although critical for the prediction of phytoplankton production, the relationship between photosynthetic rate and irradiance has not been extensively and systematically studied at Station $P$. Estimates of $\alpha$ range from about 0.2 to $1.0 \mathrm{mg} \mathrm{C}(\mathrm{mg} \mathrm{chl} \mathrm{a})^{-1} \mathrm{ly}^{-1}$ (Takahashi et al. 1972, Parslow 1981, M. J. Perry pers. comm.), but even higher, perhaps unrealistic, estimates were reported by Anderson et al. (1977). A seasonally invariant value chosen for $\alpha, 0.75$, gave the photosynthesis vs irradiance relations illustrated in Fig. $3 \mathrm{~B}$ for times of extreme mixed layer temperatures. However, the implications of larger and smaller $\alpha$ will also be investigated.

The photosynthetic rate potentially was affected by nutrient concentration (nitrogen was the assumed limiting nutrient). If light was not limiting, the dependence of chlorophyll a-specific photosynthetic rate on nutrient concentration took the form

$$
\operatorname{mgC}(\operatorname{mg~chl~} a)^{-1} \mathrm{~d}^{-1}=\frac{(\operatorname{PMAX} \cdot) \mathrm{N}}{\mathrm{d}+\mathrm{N}}
$$

where $\mathrm{N}=$ nutrient concentration in the mixed layer; and $\mathrm{d}=$ nutrient concentration $\left(1 \mathrm{mM} \mathrm{N} \mathrm{m}^{-3}\right)$ at which photosynthetic rate is half the maximum rate.

The photosynthetic rate of the phytoplankton at any depth $\mathrm{z}$ in the mixed layer was therefore

$$
\operatorname{mgCm} m^{-3} d^{-1}=\text { PMAX } \cdot \tanh \left(\frac{\alpha \text { PAR }_{z}}{\operatorname{PMAX}^{*}}\right) \frac{\mathrm{N}}{\mathrm{d}+\mathrm{N}} \cdot \mathrm{P} \cdot
$$

\section{Respiration rate of phytoplankton}

Phytoplankton respiration was assumed proportional to PMAX (Steemann Nielsen 1974, Parsons et al. 1984).

$$
\mathrm{mgC} \mathrm{m}^{-3} \mathrm{~d}^{-1}=\mathrm{r}(\mathrm{PMAX}) \mathrm{P}
$$

Although uncertainty exists about the value of $r$, Parsons et al. (1984) suggest $r=0.1$, which gives compensation irradiance levels (PAR) of $2.4 \mathrm{ly} \mathrm{d} \mathrm{d}^{-1}$ at $5{ }^{\circ} \mathrm{C}$ (Day 90) and $8.4 \mathrm{ly} \mathrm{d} \mathrm{d}^{-1}$ at $12{ }^{\circ} \mathrm{C}$ (Day 240) when $\alpha=0.75$ in the model; these values fall in the range of compensation irradiances reported by Parsons et al. (1984).

\section{Production rate of phytoplankton}

Production Rate $=$ Photosynthetic Rate - Respiration Rate

The daily phytoplankton production in the mixed layer was obtained by summing the daily production rates calculated for each $1 \mathrm{~m}$ layer.

\section{Sources of mortality of phytoplankton}

In the model phytoplankton were lost from the mixed layer by mixing of cells below the pycnocline and by grazing. It was assumed that phytoplankton mixed below the pycnocline die (Fig. 1), so that no viable phytoplankton were returned to the mixed layer from the deeper layer. Mixing loss of phytoplankton was the product $v \mathrm{P}$, where $\mathrm{v}=$ the fraction of the mixed layer replaced each day by water from the deeper layer. The value for $v, 0.01 \mathrm{~d}^{-1}$, is compatible with estimates of vertical eddy diffusion coefficients and vertical profiles of chlorophyll a at Station P (Anderson et al. 1977); in reality the intensity of vertical mixing must vary seasonally.

To be logically consistent, after Day 260, when the mixed layer deepened at the constant rate of $0.76 \mathrm{~m} \mathrm{~d}^{-1}$ (Fig. 2A), the phytoplankton should be diluted at the rate $\left(0.76 / \mathrm{z}_{\mathrm{m}}\right) \mathrm{d}^{-1}$ (Evans \& Parslow 1985). Though not included in all versions of the model, the effect of such dilution was examined, as noted later.

The representation of grazing losses will be elaborated in steps in later sections. To illustrate the structure of the model grazing loss is taken for now as a simple fractional daily loss, mP.

\section{Concentration of nutrient in the mixed layer}

The nutrient potentially limiting phytoplankton growth (assumed to be nitrogen) was depleted in the mixed layer by phytoplankton growth and was replenished by mixing from below the pycnocline, and by excretion by grazers. Nutrient was added daily to the mixed layer according to

$$
\mathrm{v}\left(\mathrm{N}_{0}-\mathrm{N}\right)
$$

where $\mathrm{N}_{0}=$ nutrient concentration below the mixed layer. $N_{0}$ varies seasonally as the mixed layer depth varies at Station P (Anderson et al. 1969, 1977), and an average seasonal cycle of $\mathrm{N}_{0}$ was used in the model (Fig. 2B).

Excretion by grazers was taken as $30 \%$ of the phytoplankton nitrogen ingested by grazers. No distinction was made between the forms of nitrogen (e. $\mathrm{g}$. ammonia, urea, nitrate) available to the phytoplankton for growth. 


\section{Equations of the model}

With grazing represented as a simple fractional loss, the concentrations of phytoplankton and nutrient in the mixed layer were determined by 2 difference equations. At time $t+1 d$ the stock of phytoplankton and concentration of nutrient in the mixed layer were calculated from

$$
\begin{aligned}
& P_{t+1}=P_{t}+\frac{\Delta P}{\Delta t} \\
& \frac{\Delta \mathrm{P}}{\Delta t}=\frac{1}{z_{\mathrm{m}}}\left\{\sum_{\mathrm{z}=0}^{z_{\mathrm{rn}}} \mathrm{P}^{*} \mathrm{PMAX}^{*} \tanh \left(\frac{\alpha \mathrm{PAR}_{z}}{\mathrm{PMAX}^{*}}\right) \frac{\mathrm{N}}{\mathrm{d}+\mathrm{N}}\right. \\
& -\mathrm{r}(\mathrm{PMAX}) \mathrm{P}\}-\mathrm{vP}-\mathrm{mP} \\
& N_{t+1}=N_{t}+\frac{\Delta N}{\Delta t} \\
& \frac{\Delta N}{\Delta t}=-\frac{1}{z_{m}}\left\{\sum_{z=0}^{z_{m}} P^{*} P_{M A X} \cdot \tanh \left(\frac{\alpha P^{2} R_{z}}{\text { PMAX }^{*}}\right) \frac{N}{d+N}\right\} \\
& +v\left(N_{0}-N\right)+0.3 m P
\end{aligned}
$$

Following Steele (1974), the dynamics of the dissolved nitrogen pool were described in the model in terms of carbon equivalents ( $1 \mathrm{mM} \mathrm{N}=75.6 \mathrm{mgC}$ ). Eqns (13) and (14), together with equations describing the change with time of incident solar radiation, mixed layer depth, mixed layer temperature, $\mathrm{N}_{0}$, and $\mathrm{c}$ (Fig. 2 \& $3 \mathrm{~A}$ ), constituted the model. Parameter values for all versions of the model are given in Table 1.

Eqns (13) and (14) were integrated over $1 \mathrm{~d}$ time intervals for $365 \mathrm{~d}$. A comment about the numerical solution is warranted. Because of non-linearity of the photosynthesis-light relation, different rates of phytoplankton production were predicted by the model depending on whether daily photosynthesis was calculated as a function of daily irradiance received in each $1 \mathrm{~m}$ stratum of the mixed layer (the procedure described above) or if daily photosynthesis was the sum of rates calculated on shorter time scales (e.g. hourly) using a reconstructed diel cycle of irradiance (method outlined by Evans \& Parslow 1985). For a given set of values of parameters and concentration of chlorophyll, the latter procedure gave significantly lower estimates of daily phytoplankton production (cf. Platt et al. 1984). However, there were 2 reasons for choosing to integrate our daily time intervals. First, uncertainty in the values of parameters of phytoplankton growth, particularly $\alpha$ and $r$, allowed for extensive overlap in the ranges of predicted annual phytoplankton production by the 2 integration schemes. Second, integration on time scales shorter than a day required additional assumptions to represent diel periodicity of physiological processes and behavior in both phytoplankton and herbivorous zooplankton. This may well be of interest (e.g. McAllister 1970, Fasham et al. 1983), particularly when more specific information becomes available on physiological and behavioral diel periodicity in the plankton of the open subarctic Pacific.

In these calculations it was also implicitly assumed that the mixed layer was not only actively mixing at all times, but that the time scale for mixing was much shorter than the time scale for phytoplankton to adapt

\begin{tabular}{|c|c|c|c|c|}
\hline $\begin{array}{l}\text { Para- } \\
\text { meter }\end{array}$ & $\begin{array}{l}\text { Expt } 1 \\
\text { (Fig. 4) }\end{array}$ & $\begin{array}{c}\text { Expt } 2 \\
\text { (Fig. 7) }\end{array}$ & $\begin{array}{l}\text { Expt } 3 \\
\text { (Fig. 8) }\end{array}$ & $\begin{array}{c}\text { Expt } 4 \\
\text { (Fig. } 10 \& 11)\end{array}$ \\
\hline a & 0.02 & 0.02 & 0.02 & 0.02 \\
\hline $\mathrm{b}$ & 0.1 & 0.1 & 0.1 & 0.1 \\
\hline$\alpha$ & 0.75 & 0.75 & 0.75 & 0.75 \\
\hline c & $15-45$ & $15-45$ & $15-45$ & $15-45$ \\
\hline d & 1.0 & 1.0 & 1.0 & 1.0 \\
\hline $\mathrm{r}$ & 0.1 & 0.1 & 0.1 & 0.1 \\
\hline $\mathrm{e}$ & - & - & $0.98-1.59$ & $0.98-1.59$ \\
\hline$e^{\prime}$ & - & - & - & $0.123-0.20$ \\
\hline $\mathrm{f}$ & - & - & 25.0 & 25.0 \\
\hline $\mathrm{f}^{\prime}$ & - & - & - & 50.0 \\
\hline$g$ & - & - & $0.20-0.325^{\circ}$ & - \\
\hline $\mathrm{h}$ & - & - & 50.0 & - \\
\hline $\mathrm{m}$ & $\cdots$ & $\cdots$ & - & - \\
\hline$P_{0}$ & - & 5.0 & 5.0 & \\
\hline $\mathrm{v}$ & 0.01 & 0.01 & 0.01 & 0.01 \\
\hline
\end{tabular}
to saturating irradiance. Thus, although daily phytoplankton production was calculated in $1 \mathrm{~m}$ strata, the phytoplankton stock was always homogeneously dis-

Table 1. Values of fixed and variable parameters used in the model

persed over the mixed layer, a process implied by the homogeneous distribution of chlorophyll usually observed at Station P (Anderson et al. 1977).

Since, as noted by Evans \& Parslow (1985), the predicted dynamics of plankton production vary with initial conditions, a steady annual cycle was obtained for each version of the model by taking as initial conditions the stock of phytoplankton and, when applicable, zooplankton, and the concentration of nutrient at Day 365 of an initial simulation. Four experiments were done to test the grazing hypothesis by using the model, and elaborations of it, to reproduce the annual cycle of phytoplankton standing stock and production in the mixed layer. 


\section{Comparison of model predictions and observations}

Estimates of phytoplankton production rate were obtained for several years at Station $\mathrm{P}$ by relatively standard procedures (McAllister 1969). Uptake of ${ }^{14} \mathrm{C}$ was determined in samples taken from 5 or 6 depths and incubated on deck from noon to $1800 \mathrm{~h}$ (local time) under simulated in situ light conditions. Parslow (1981) noted some methodological problems with the productivity estimates which preclude detailed comparison of the data with model predictions. Data collected after 1968 are particularly suspect and are not considered further here. Most of the usable data, 60 vertical profiles, were obtained in the years 1961 to 1967. The reported daily (McAllister 1962, Stephens 1964) or hourly (Stephens 1966, 1968) carbon fixation rates were integrated over the photic zone (surface to depth of $1 \%$ of surface irradiance, calculated using observed Secchi depths or long-term mean Secchi depth for the particular month [Stephens 1966]). Daily carbon fixation rates were converted to hourly rates by dividing by 12 . Since incubations were short-term, of standard duration, and - depending on time of year - included a variable fraction (always half or less) of the daylight hours, the most appropriate data from the model to compare with observations are the predicted hourly production rates. Consequently, in addition to calculating daily phytoplankton production rate as described above, hourly production rate was calculated as a standard $1 / 12$ of the daily rate.

\section{RESULTS}

\section{Experiment 1 - assume grazing hypothesis correct}

For the initial application of the model it was assumed that all phytoplankton net production was removed each day by the combined effects of mixing and grazing (with a fraction of the grazed phytoplankton returned to the mixed layer as recycled nitrogen). This by definition gave a constant phytoplankton stock through time. It also logically constrained phytoplankton net production to be zero or positive at all times. Additional justification for this is that negative growth of phytoplankton in winter is incompatible with observations at Station $P$, otherwise standing stock of phytoplankton would decline to very low levels in winter, relative to other seasons. Recent analysis of Station $P$ data (Frost et al. 1983; see also Anderson et al. 1977) indicated a mean concentration of $0.3 \mathrm{mg}$ chlorophyll $a \mathrm{~m}^{-3}$ in the euphotic zone throughout the year. The objective of this experiment was to determine the expected annual cycles of phytoplankton production and nutrient concentration in the mixed layer.

With the concentration of phytoplankton held at 0.3 $\mathrm{mg}$ chl a $\mathrm{m}^{-3}$, the model predicted annual cycles of phytoplankton production and nutrient concentration that may be compared with observations from Station $\mathrm{P}$
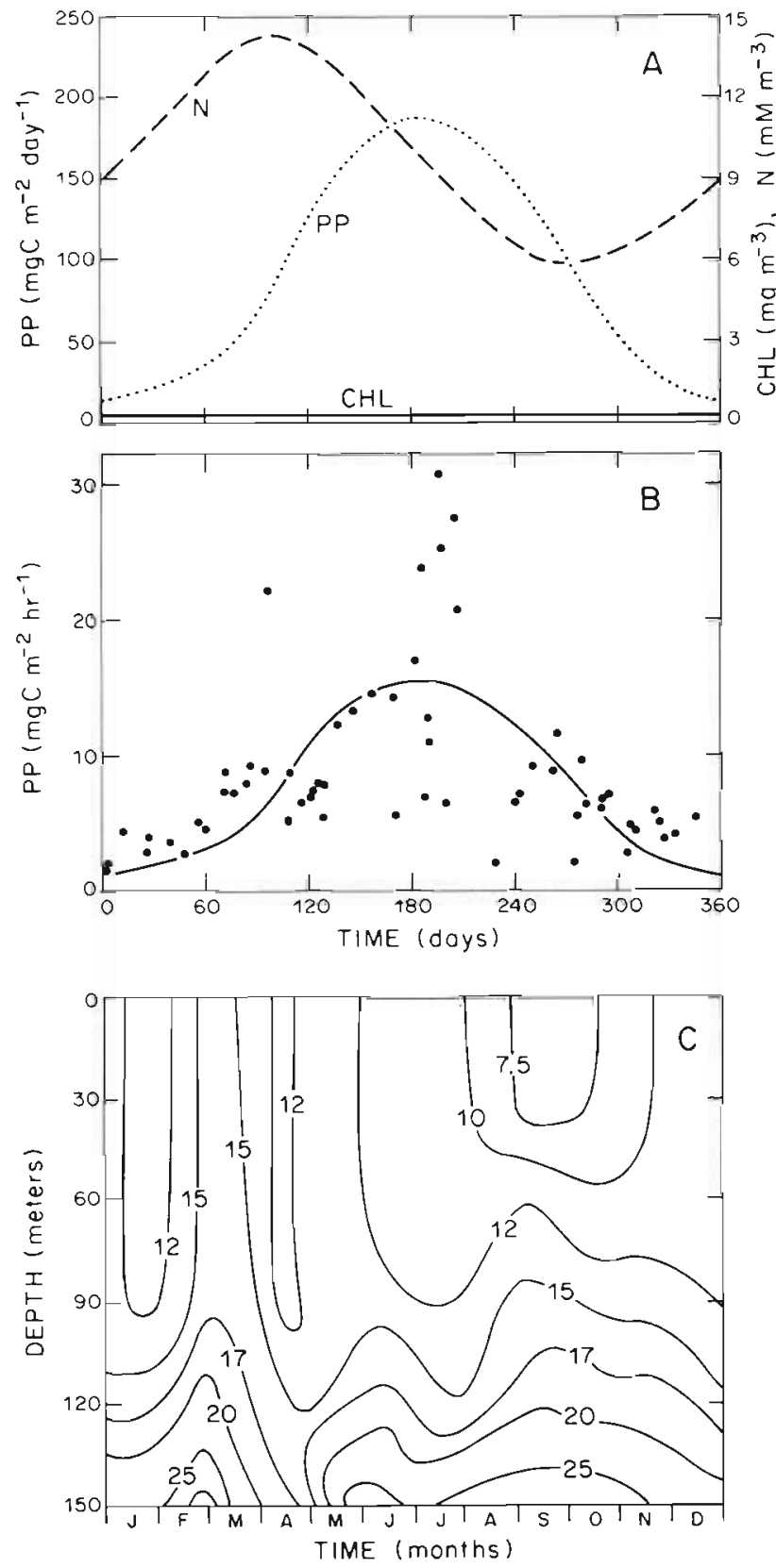

Fig. 4. (A) Annual cycle of phytoplankton production rate (PP) and nutrient concentration $(\mathrm{N})$ in the mixed layer predicted by the model with phytoplankton concentration ( $\mathrm{CHL}$ ) held at $0.3 \mathrm{mg} \mathrm{m}^{-3}$. (B) Observations ( $\bullet$ ) of phytoplankton production rate (PP) integrated over the photic zone at Station $\mathrm{P}$ (data for 1961 to 1967), and mixed layer phytoplankton production rate predicted by the model (curve); curve was obtained by dividing daily production rates in (A) by 12 . At Station $\mathrm{P}$ the photic zone was 20 to $60 \mathrm{~m}$ deep; from May to September mean photic zone depth was $34 \mathrm{~m}$. (C) Nitrate concentration (mM N $\mathrm{m}^{-3}$ ) at Station P, 1965 to 1971 (adapted from Anderson et al. 1977; see also Anderson et al. 1969) 
Table 2. Estimates of phytoplankton standing stock $\left(\mathrm{P}^{*}, \mathrm{mg}\right.$ chl $a \mathrm{~m}^{-3}$ ) and production rate (PP, $\mathrm{mgC} \mathrm{m}^{-2} \mathrm{~d}^{-1}$ ) at Station $P$ (C. J. Lorenzen pers. comm.). Production rates are based on ${ }^{1.4} \mathrm{C}$ uptake in samples incubated in situ from sunrise to sunset at 4 or 5 depths

\begin{tabular}{|lcc|}
\hline Date & $\begin{array}{c}\text { Mean } P^{*} \\
(0-30 \mathrm{~m})\end{array}$ & $\begin{array}{c}\text { PP } \\
(0-30 \mathrm{~m})\end{array}$ \\
\hline 2 May 1984 & 0.13 & 100 \\
11 May 1984 & 0.35 & 186 \\
& & \\
6 Jun 1978 & 0.20 & 240 \\
10 Jun 1978 & 0.20 & 406 \\
12 Jun 1978 & 0.21 & 403 \\
3 Aug 1984 & 0.23 & 192 \\
6 Aug 1984 & 0.18 & 203 \\
\hline
\end{tabular}

(Fig. 4). Many of the spring and summer observations fall well below levels predicted by the model. However, the few apparently high observations in late spring and summer (Fig. 4B) are consistent with recent estimates obtained in the same seasons at Station P (Table 2) and with observations in spring and summer from the central subarctic Pacific to the west of Station P (Larrance 1971). Chiefly on the basis of these recent observations it appears improbable that the model (Fig. 4A) overestimated phytoplankton production rate even in late spring and summer; the model is therefore considered to give conservative predictions of phytoplankton production rate. However, because there clearly is not overwhelming evidence backing this opinion, a range of model predictions, in addition to that in Fig. 4A, will be considered in later sections. The predicted annual phytoplankton production rate for Fig. $4 \mathrm{~A}$ was $34.0 \mathrm{gC}$ $\mathrm{m}^{-2}$ in the mixed layer.

The predicted annual cycle of phytoplankton production was relatively unaffected by variations in the mixing coefficient $v$ over the range 0.005 to $0.05 \mathrm{~d}^{-1}$. This was because, as specified in this experiment, vertical mixing did not deplete the phytoplankton stock in the mixed layer, and also because the nutrient concentration never fell to sufficiently low levels to strongly limit phytoplankton growth. Thus, the 10 -fold range of $\checkmark$ caused annual phytoplankton production to increase from 32.8 to $34.3 \mathrm{gC} \mathrm{m}^{-2}$.

The annual cycle of mixed layer nitrate predicted by the model paralleled the trend in the observations (Fig. 4). It should be noted that the predicted annual cycle of nitrate in the mixed layer was determined not only by phytoplankton production, but also by the annual cycle of $N_{0}$ (Fig. 2B). The latter could be construed as a gross parameterization of nutrient depletion due to uptake by phytoplankton living below the mixed layer (alluded to earlier), but the annual cycle must also depend on seasonal variation in vertical mixing. Other parameters in the model remaining unchanged, if $\mathrm{v}$ was lower in summer, the predicted nutrient concentration in the mixed layer was also lower. Thus, given the negligible effect of vertical mixing on phytoplankton production rate noted above, the predicted annual cycle of nutrient concentration appears not to be a strong quantitative indicator of the level of phytoplankton production, but only of the timing of the production cycle.

The late summer minimum nitrate concentration predicted by the model $\left(\sim 5.8 \mathrm{mM} \mathrm{N} \mathrm{m}^{-3}\right)$ is somewhat lower than the long-term average minimum ( 7.5), no doubt because sources of nutrient recycling other than excretion by grazers (e.g. excretion by bacterioplankton) were not included in the model. Furthermore, recent observations at Station P suggest that in summer ammonium is preferentially utilized over nitrate for phytoplankton growth (P. Wheeler pers. comm.). Both of these processes, not now included in the model, would account for observed nitrate concentrations being higher than those predicted by the model.

The predicted annual cycle of phytoplankton production was sensitive to, and depended directly on, the value of $\alpha$, the photosynthetic efficiency. For example, increasing or decreasing $\alpha$ by $33 \%$ shifted the curve of phytoplankton production rate up or down (Fig. 5) and increased (by $20.4 \%$ ) or decreased (by $29.2 \%$ ) the annual phytoplankton production. If $\alpha$ was less than about 0.35 net production rate of the phytoplankton was negative in winter; the duration of negative winter production increased with decreasing $\alpha$. Decreasing the respiration coefficient $\mathrm{r}$ from 0.1 to 0.05 increased annual phytoplankton production by $21 \%$ relative to that in Fig. 4A. If the carbon to chlorophyll a ratio, c,

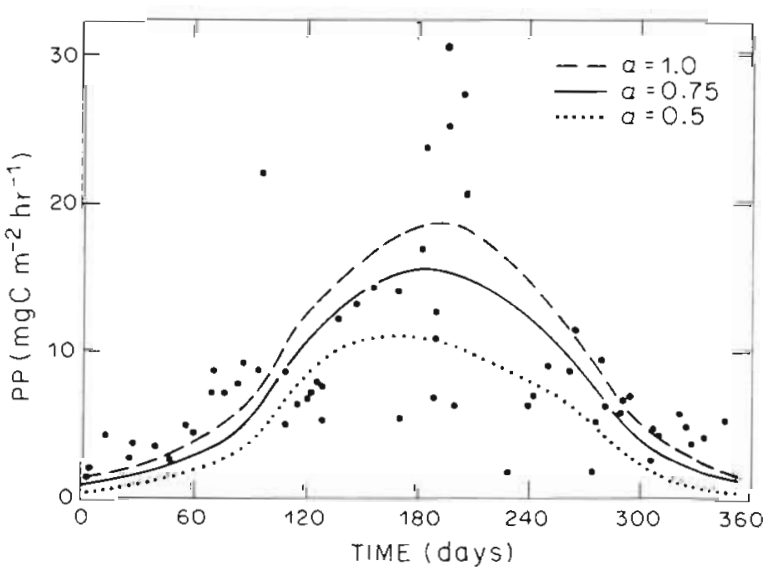

Fig. 5. Observations ( $\bullet$ of phytoplankton production rate (PP) integrated over the photic zone at Station P (see Fig. 4B), and predicted annual cycles of phytoplankton production rate (curves) with phytoplankton concentration held constant at $0.3 \mathrm{mg} \mathrm{chl} \mathrm{a} \mathrm{m} \mathrm{m}^{-3}$ 
was systematically increased, the pattern of seasonal variation in phytoplankton production changed. For example, if $\mathrm{C}$ varied from 30 to 90 according to the pattern in Fig. 3A, net production rate of the phytoplankton was substantially lower, but still positive, in winter, and higher in late spring and early summer than the rates in Fig. 4; annual production decreased slightly to $33.7 \mathrm{gC} \mathrm{m}^{-2}$. With the same seasonal variation of $c$ (30 to 90), if $\alpha$ was decreased to 0.5 , net production rate of phytoplankton would be negative for about $80 \mathrm{~d}$ in winter. Considering only cases above where net production rate of the phytoplankton was positive throughout the year, the range of annual production rates predicted by the model, 15.8 to $41.1 \mathrm{gC}$ $\mathrm{m}^{-2}$, includes the estimates based on observations at Station P (Parslow 1981).

The implications of various sources of grazing mortality were investigated in the following 3 experiments with the model. Parameters of phytoplankton growth were those used for Fig. 4A (Table 1), assuming that this gave a conservative representation of the level of phytoplankton production at Station P. However, in some experiments the effects of other annual cycles, with phytoplankton production rate differing in timing and magnitude from that in Fig. 4, and including annual cycles with negative net production of phytoplankton in winter, will be evaluated.

\section{Experiment 2 - mesozooplankton grazing}

Clearly, for grazing zooplankton to achieve the hypothesized control of the phytoplankton stock, the annual pattern of grazing mortality must closely follow that of the phytoplankton production. The mesozooplankton (animals 0.2 to $20 \mathrm{~mm}$ body length) in the mixed layer at Station $P$ includes all of the surfacedwelling developmental stages of Neocalanus spp., the hypothesized major grazers of phytoplankton. Standing stock of mesozooplankton at Station P varies seasonally in a fashion qualitatively similar to the cycle of primary production (Fig. 3 in McAllister 1969, and below), and if grazing rate of the mesozooplankton was a simple function of its standing stock, then grazing mortality might have the required annual cycle.

The grazing capacity of mesozooplankton required by the model in Experiment 1 (Fig. 4A) can be evaluated by calculating daily grazing rate $\left(\mathrm{G}, \operatorname{mgC} \mathrm{m}^{-3} \mathrm{~d}^{-1}\right)$ : $\mathrm{G}=$ phytoplankton production rate - mixing loss $=$ $\mathrm{mP}$

The required mass-specific clearance rate $[\mathrm{F}, \mathrm{l}(\mathrm{mg}$ mesozooplankton $\mathrm{C}^{-1} \mathrm{~d}^{-1}$ ] is then

$$
F=\left(\frac{G}{Z P}\right) 1000
$$

where $\mathrm{Z}=$ standing stock $\left(\mathrm{mgC} \mathrm{m}^{-3}\right)$ of mesozooplankton.

Two alternative annual cycles of $\mathrm{Z}$ were used in the model. A mean seasonal cycle of mesozooplankton standing stock at Station P was provided by J. Fulton (pers. comm.). The curve is based on standing stock measured as displacement volume of mesozooplankton ( $\mathrm{mg}$ wet weight $\mathrm{m}^{-3}$ ) in standard daytime vertical hauls (350 $\mu \mathrm{m}$ mesh nets), $150 \mathrm{~m}$ to the surface, collected during the years 1956 to 1980 (Fulton 1983). For the model, wet weight was converted to carbon (mgC = mg wet weight $\times 0.052$ ), and it was assumed that suspension feeders ('herbivores') made up $80 \%$ of the standing stock (Parsons \& LeBrasseur 1968). The effective concentration of mesozooplankton in the mixed layer $\left(\mathrm{Z}, \mathrm{mgC} \mathrm{m}^{-3}\right)$ was calculated assuming that either (a) the stock was aggregated in the upper $50 \mathrm{~m}$ or (b) the stock was restricted to, but uniformly distributed in, the mixed layer. These are likely to bracket the real vertical distributions of mesozooplankton at Station $\mathrm{P}$ (McAllister 1961, Marlowe \& Miller 1975). Because mixed layer depth varied seasonally, somewhat different seasonal patterns of $Z$ resulted (Fig. 6).

Specific clearance rate $(F)$ of mesozooplankton required by the model ranged from 6.5 to $72.6 \mathrm{I} \mathrm{mgC}^{-1}$ $\mathrm{d}^{-1}$ (Fig. 7). The different alternatives for calculating $\mathrm{Z}$ (Fig. 6) resulted in similar seasonal patterns, but different magnitudes; at any time, a more concentrated

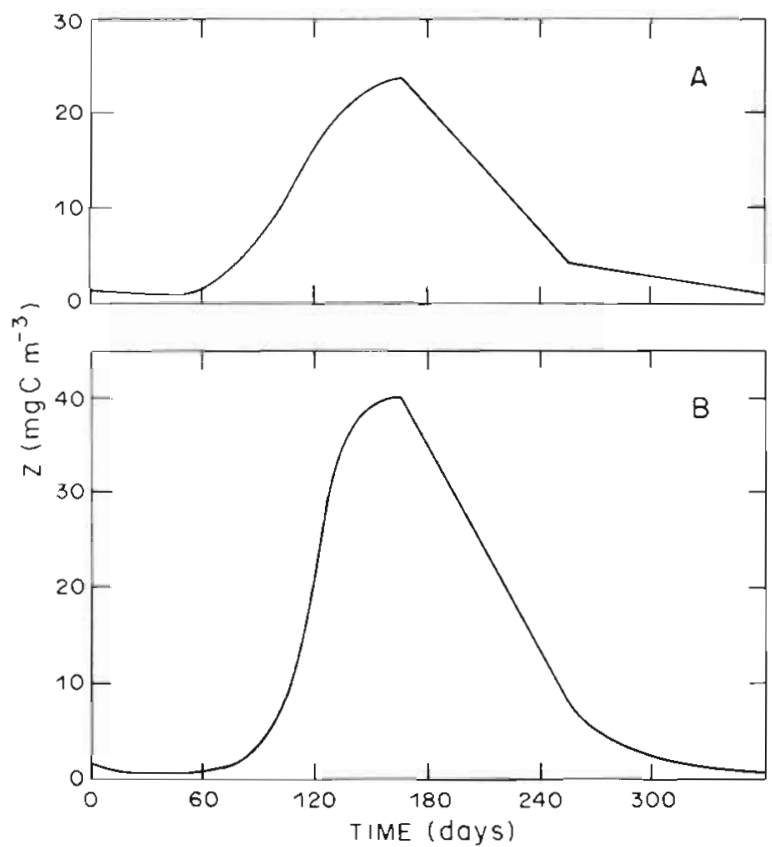

Fig. 6. Standing stock of mesozooplankton (Z) assuming that stock is aggregated in the upper $50 \mathrm{~m}(\mathrm{~A})$ or is homogeneously distributed in the mixed layer (B). Based on average standing stock of mesozooplankton observed at Station P (data provided by J. Fulton) 


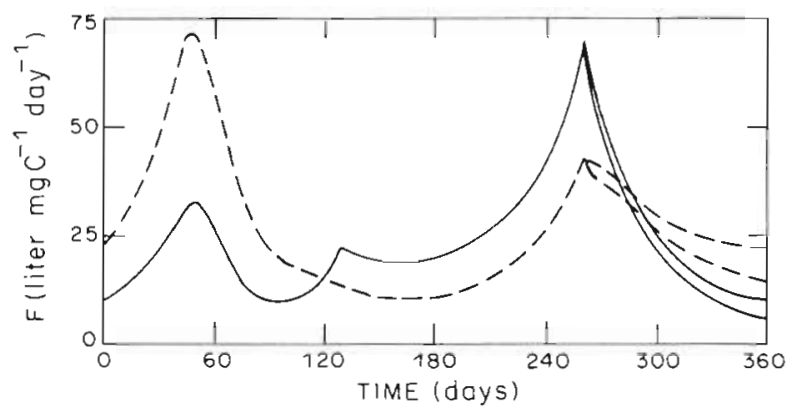

Fig. 7. Mass-specific clearance rate $(\mathrm{F})$ that must be exerted by mesozooplankton stock to maintain constant standing stock of phytoplankton when phytoplankton production was modelled as in Fig. 4. Solid line, mesozooplankton concentrated in the upper $50 \mathrm{~m}$ (Fig. 6A); dashed line, mesozooplankton aggregated in the mixed layer (Fig. 6B). Bifurcations of curves at Day 260 represent cases with (lower branch of curves) and without (upper branch) dilution of phytoplankton due to increasing depth of the mixed layer

mesozooplankton had, of course, lower required $\mathrm{F}$. Between Days 30 and 330 the minimum required $F$, $9.7 \mathrm{l} \mathrm{mgC}-1 \mathrm{~d}^{-1}$, is greater than the maximum massspecific clearance rate measured for any species of planktonic suspension feeder in the size-range of mesozooplankton, including gelatinous species (Andersen 1985). To relate the argument more specifically to Station $\mathrm{P}$, at Day 170 in the model, when $\mathrm{Z}$ was at its seasonal maximum, required values of $F$ ranged from 11.0 to $18.4 \mathrm{l} \mathrm{mgC}^{-1} \mathrm{~d}^{-1}$. At Station $P$ in late June the suspension-feeding mesozooplankton is dominated by the older copepodid stages of Neocalanus plumchrus and $N$. cristatus (Miller et al. 1984). These species clearly are incapable of such high specific clearance rates on a sustained basis; maximum mass-specific clearance rates, sustained over periods of about a day, were about 0.4 to $3.61 \mathrm{mgC}^{-1} \mathrm{~d}^{-1}$ for copepodid Stage $\mathrm{V}$ of $N$. plumchrus and only $0.4 \mathrm{lmgC}^{-1} \mathrm{~d}^{-1}$ for copepodid Stage V of $N$. cristatus (Dagg et al. 1982, Frost et al. 1983, Dagg \& Wyman 1983, Dagg \& Walser 1987, M. R. Landry pers. comm.).

The mismatch between specific clearance rates required by the model and grazing capacity of mesozooplankton was as bad for other seasons. For example, Fig. 7 suggests that winter (Days 30 to 90), when the standing stock of mesozooplankton was at the seasonal low, was one critical period in view of the very high clearance rates required. Since copepodid Stages I to IV comprise most of the populations of Neocalanus plumchrus and $N$. cristatus in winter at Station P (Miller et al. 1984), specific clearance rates of the mesozooplankton could be higher because of smaller body size of the suspension feeders. An appreciation of the magnitude of this effect can be gained by rescaling maximum clearance rates. to copepods of smaller body sizes. The highest sustained clearance rate for copepodid Stage $V$ of $N$. plumchrus (body mass $200 \mu \mathrm{gC}$ ) was about $600 \mathrm{ml}$ copepod ${ }^{-1} \mathrm{~d}^{-1}$ at $8^{\circ} \mathrm{C}$ (Dagg \& Walser 1987 ). Using the power function, $\mathrm{F}=\beta \mathrm{W}^{0.75}$ for the mass dependence of clearance rate (Huntley \& Boyd 1984), and assuming the mesozooplankton consists entirely of middle-sized copepodid stages of $N$. plumchrus whose body masses are 25 to $50 \mu \mathrm{gC}$, gives maximum specific clearance rates of about 4 to $5 \mathrm{lmgC} \mathrm{mg}^{-1} \mathrm{~d}^{-1}$. These rates, surely overestimates for the suspension-feeding mesozooplankton, are still much lower than the 13.2 to 72.61 $\mathrm{mgC}^{-1} \mathrm{~d}^{-1}$ required during Days 30 to 90 in the model (Fig. 7).

The same conclusion holds if predicted phytoplankton production rate is lower. For example, with $\alpha=0.5$ (Fig. 5), giving $24.1 \mathrm{gC} \mathrm{m}^{-2}$ annual phytoplankton production, required values of $F$ ranged from 6.4 to $49.21 \mathrm{mgC}^{-1} \mathrm{~d}^{-1}$ between Days 30 and 300; rates on Day 170 were 8.1 and 13.6. On the other hand, if the carbon-to-chlorophyll ratio, $\mathrm{C}$, was systematically doubled, varying between 30 and 90 according to the pattern in Fig. 3A, required values of $F$ were, as expected, substantially lower, ranging from 2.5 to 32.1 between Days 30 and 300. Indeed, in the case of mesozooplankton concentrated in the upper $50 \mathrm{~m}$ there were times in winter (Days 30 to 40,80 to 100 ) when it was within the capacity of the mesozooplankton, if predominantly Neocalanus plumchrus, to control phytoplankton stock. However, between Days 110 and 300 the required values of $F$ still exceeded 6.0 whether mesozooplankton was concentrated in the upper $50 \mathrm{~m}$ or in the mixed layer. Of course, if phytoplankton production rate at Station $\mathrm{P}$ was underestimated by the model (Fig. 4A), then mesozooplankton would have to exert proportionately higher clearance rate to maintain constant phytoplankton stock.

The possibility that standing stock of suspensionfeeding mesozooplankton was systematically undersampled at Station $P$ must be considered. The standard vertical hauls were taken in the daytime (usually $0900 \mathrm{~h}$ local time), and there may be bias toward underestimated of species whose diel vertical migrations taken them below $150 \mathrm{~m}$ in the daytime (McAllister 1961, Marlowe \& Miller 1975) and of species which can avoid vertically hauled nets in the daytime. There is no way to assess these effects in the historical data set, but recent studies of vertical distribution of mesozooplankton with vertically towed $0.5 \mathrm{~m}$ diameter nets and with larger, obliquely towed, multiple net samplers indicated slight vertical migratory behavior by all species of Neocalanus and no evidence of lightaided avoidance (D. L. Mackas \& C. B. Miller pers. comm.).

The model results indicate that mesozooplankton do 
not have sufficient grazing capacity to be solely responsible for control of the phytoplankton stock at Station $\mathrm{P}$.

\section{Experiment 3 - microzooplankton grazing}

If the grazing hypothesis is to remain viable, there must be another source of grazing besides the mesozooplankton. The purpose of this experiment was to evaluate the potential of microzooplankton (animals 0.02 to $0.2 \mathrm{~mm}$ in length) as major grazers of phytoplankton in the open subarctic Pacific. Because very little is known about microzooplankton in the open subarctic Pacific, particularly organisms smaller than $44 \mu \mathrm{m}$ effective diameter (LeBrasseur \& Kennedy 1972), this is out of necessity an entirely hypothetical elaboration of the model. Nevertheless, some sensible limits on the required abundances, feeding rates, and growth rates of microzooplankton could be obtained by assuming that they are the major grazers of phytoplankton. The model was therefore modified to include a population of microzooplankton grazers whose feeding and growth characteristics resembled a tintinnid ciliate, a relatively large microzooplankter; Heinbokel's (1978) experimental results served as the basis for the description of the microzooplankton. Following the approach of Evans \& Parslow (1985), the growth of the microzooplankton grazer assemblage was explicitly modelled as the balance between its production and its mortality due to predation.

Phytoplankton growth was described as in Experiment 1 (Fig. 4A), except that the grazing term, $\mathrm{mP}$, in Eqns (13) and (14) was replaced by a term for ingestion rate of the microzooplankton grazer assemblage:

$$
\mathrm{mgC} \mathrm{m}^{-3} \mathrm{~d}^{-1}=\frac{\mathrm{e}\left(\mathrm{P}-\mathrm{P}_{0}\right) \mathrm{H}}{\mathrm{f}+\left(\mathrm{P}-\mathrm{P}_{0}\right)}
$$

where $e=$ maximum mass-specific grazing rate $(\mathrm{mgC}$ $\left.\mathrm{mgC}^{-1} \mathrm{~d}^{-1}\right) ; \mathrm{P}_{0}=$ phytoplankton concentration (mgC $\mathrm{m}^{-3}$ ) below which grazing ceases $\mathrm{f}^{\mathrm{f}}=$ phytoplankton concentration giving half the maximum grazing rate at $\mathrm{f}+\mathrm{P}_{\mathrm{O}}$; and $\mathrm{H}=$ standing stock $\left(\mathrm{mgC} \mathrm{m}^{-3}\right)$ of the microzooplankton grazer assemblage. Heinbokel (1978) found that several tintinnid species had maximum mass-specific ingestion rates of 10 to $20 \% \mathrm{~h}^{-1}$ at $18^{\circ} \mathrm{C}$ (see also Verity 1985). Taking the lower value in the range, and adjusting the rate to $5{ }^{\circ} \mathrm{C}$ (the minimum mixed layer temperature in the model) using $Q_{10}=2.0$,

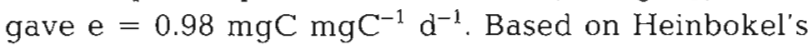
(1978) Fig. 7, the parameters $f$ and $P_{0}$ were estimated: $\mathrm{f}=25$ and $\mathrm{P}_{0}=5 \mathrm{mgC} \mathrm{m}{ }^{-3}$. According to Heinbokel's results herbivorous tintinnids can convert ingested phytoplankton into their cell substance with up to $50 \%$ efficiency. In the model the remaining $50 \%$ of ingested phytoplankton was partitioned between egested fecal material ( $20 \%$, assumed lost from the mixed layer) and excreted nitrogenous metabolites $(30 \%)$. Production rate of the microzooplankton grazers was therefore

$$
\mathrm{mgC} \mathrm{m} \mathrm{m}^{-3} \mathrm{~d}^{-1}=0.5 \frac{\mathrm{e}\left(\mathrm{P}-\mathrm{P}_{0}\right) \mathrm{H}}{\mathrm{f}+\left(\mathrm{P}-\mathrm{P}_{0}\right)}
$$

Specific mortality rate due to predation was assumed density-dependent:

$$
\mathrm{mgC} \mathrm{mgC}^{-1} \mathrm{~d}^{-1}=\frac{\mathrm{gH}}{\mathrm{h}+\mathrm{H}}
$$

where $\mathrm{g}=$ coefficient of maximum predation mortality (fraction of the grazer stock removed per day); and $\mathrm{h}=$ grazer standing stock ( $\mathrm{mgC} \mathrm{m}^{-3}$ ) giving $0.5 \mathrm{~g}$. There is no observational basis for selecting values of $\mathrm{g}$ and $\mathrm{h}$; values were chosen to give reasonable estimates of annual phytoplankton production. The parameters $\mathrm{e}$ and $g$ were functions of temperature (temperature dependency $Q_{10}=2.0$ ). Over the seasonal range of mixed layer temperature (Fig. $2 \mathrm{~b}$ ) e varied from 0.98 to 1.59 and $g$ varied from 0.20 to 0.325 . Parameter h took the value 50. For comparison with Evans \& Parslow's (1985) results, the effect of density-independent predation was also investigated. That is, mortality rate due to predation was

$$
\mathrm{mgC} \mathrm{m}^{-3} \mathrm{~d}^{-1}=\mathrm{gH}
$$

where $\mathrm{g}$ was in this case a temperature-independent constant. Microzooplankton grazers were also removed from the mixed layer by vertical mixing $(\mathrm{vH})$ and, like the phytoplankton, assumed to die below the mixed layer.

The model now consisted of Eqns (13) and (14), modified as just described, and an equation for the dynamics of herbivorous microzooplankton:

$$
\begin{gathered}
\mathrm{H}_{\mathrm{t}+1}=\mathrm{H}_{\mathrm{t}}+\frac{\Delta \mathrm{H}}{\Delta \mathrm{t}} \\
\frac{\Delta \mathrm{H}}{\Delta \mathrm{t}}=\left[0.5 \frac{\mathrm{e}\left(\mathrm{P}-\mathrm{P}_{0}\right)}{\mathrm{f}+\left(\mathrm{P}-\mathrm{P}_{0}\right)}-\frac{\mathrm{gH}}{\mathrm{h}+\mathrm{H}}-\mathrm{v}\right] \mathrm{H}
\end{gathered}
$$

Parameter values are summarized in Table 1.

In this version of the model, with parameters of phytoplankton growth as described in Fig. 4A, phytoplankton stock was readily controlled by the microzooplankton grazer with a broad range of values of the parameters specifying the growth and mortality of the grazer. In Fig. 8, for example, the phytoplankton standing stock was always less than $0.45 \mathrm{mg} \mathrm{chl} \mathrm{a} \mathrm{m}^{-3}$, the annual cycle of nutrient concentration was consistent with observations, and the annual phytoplankton production rate, $28.0 \mathrm{gC} \mathrm{m}^{-2}$, was reasonable. The model predicted a substantial stock of herbivorous microzooplankton, 17 to $28 \mathrm{mgC} \mathrm{m}^{-3}$ in Fig. 8, from late spring 


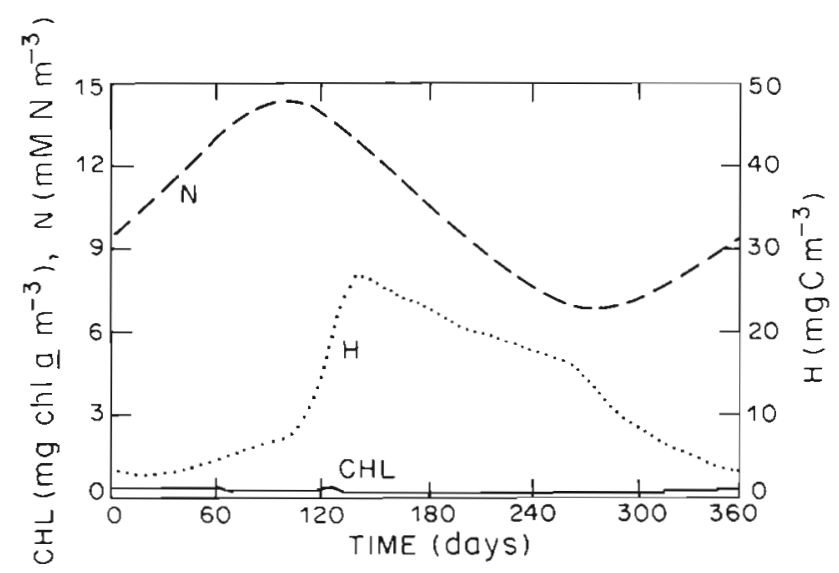

Fig. 8. Annual cycles of phytoplankton standing stock (CHL), herbivorous microzooplankton $(\mathrm{H})$, and nutrient concentration $(N)$ in the mixed layer, predicted by the version of the model described in Experiment 3

through summer. The predicted stock depended on the value of $e$, on the growth efficiency of the grazer, and on the predation rate $\mathrm{g}$. Changes in these parameters not only caused changes in the predicted peak standing stock of microzooplankton, but also the predicted annual phytoplankton production rate (Table 3 ).

With reference to continuous maintenance of a low stock of phytoplankton by grazers, the model clearly was most sensitive to change in the growth efficiency of the herbivorous microzooplankton. The small peak in concentration of chlorophyll a predicted for Day 130 (Fig. 8) increased from 0.37 to $0.85 \mathrm{mg} \mathrm{m}^{-3}$ when growth efficiency decreased from 50 to $30 \%$. Brief pulses (dissipated by Day 150) of phytoplankton production rate and stock of herbivorous microzooplankton occurred concurrently. At the time that the mixed layer was shoaling in the model (Days 90 to 130), sustained control of the phytoplankton stock by herbivorous microzooplankton depended on the ability of

Table 3. Changes in predicted annual phytoplankton production rate (P) and standing stock of herbivorous microzooplankton $(H)$ at Day 180 when a single parameter of the model was changed. Model is described in Experiment $3 .+$ or - in parentheses indicate that the parameter value was higher or lower than value in Fig. 8

\begin{tabular}{|lccc|}
\hline Parameter & Value & \multicolumn{2}{c|}{$\begin{array}{c}\text { change relative to } \\
\text { values in Fig. 8 } \\
\end{array}$} \\
& & $\mathrm{H}$ & $\mathrm{P}$ \\
\hline $\mathrm{e}$ & $1.96-3.18(+)$ & -16.3 & -21.8 \\
Gross eff. & $30 \%(-)$ & -16.2 & +25.6 \\
$\mathrm{~g}$ & $0.10-0.162(-)$ & +31.8 & -12.9 \\
$\mathrm{~g}$ & $0.30-0.487(+)$ & -12.5 & +12.5 \\
$\alpha$ & $0.5(-)$ & -20.8 & -33.0 \\
$\alpha$ & $1.0(+)$ & +14.3 & +24.8 \\
\hline
\end{tabular}

the grazers to respond fast enough, by increase in both their feeding rate (functional response) and standing stock (numerical response) to match the increase in phytoplankton growth rate. Growth efficiency was an obvious constraint for the grazer. For none of the other manipulations of parameters, reported in Table 3 , did the chlorophyll concentration ever exceed $0.5 \mathrm{mg} \mathrm{m}^{-3}$.

The predicted concentration of chlorophyll a was somewhat variable, both on short-term and on broadly seasonal time scales (Fig. 8). The seasonal cycle, with values ranging from $0.19 \mathrm{mg}$ chlorophyll $\mathrm{a} \mathrm{m}^{-3}$ in midsummer to 0.43 in mid-winter, was inversely correlated with the seasonal cycle of $c$, the carbon-to-chlorophyll a ratio; however, the small increase in chlorophyll a (to nearly $0.4 \mathrm{mg} \mathrm{m}^{-3}$ ) around Day 130 was, as noted above, associated with phytoplankton-grazer dynamics at the time that the shallow seasonal thermocline was forming. In both magnitude and seasonality, the predicted variation falls well within the range of observations at Station P (Clemons \& Miller 1984).

A low, non-zero threshold food concentration $\left(\mathrm{P}_{0}\right)$ was required, when grazing was formulated as Eqn (17), to obtain realistic concentration of chlorophyll a and to prevent phytoplankton from being grazed to extinction. Considerable evidence for some sort of threshold feeding behavior, either reduced feeding rate or complete cessation of feeding at very low phytoplankton abundance, is available for a variety of marine suspension-feeders, even protozoans (Capriulo 1982, Caron et al. 1985). However, grazing does not have to take the form of Eqn (17) to obtain in the model an annual cycle with phytoplankton stock controlled throughout the year. An optimal foraging type of feeding response (Steele \& Frost 1977) may be used, with herbivore ingestion rate (I) taking the form

$$
\begin{array}{ll}
I=e m P^{2} & \text { for } P<P_{\text {crit }} \\
I=e P & \text { for } P \geq P_{\text {crit }}
\end{array}
$$

and

where e was defined above (Eqn 17); and $q=a$ constant. This made microzooplankton grazers very effective at keeping phytoplankton stock well below the concentration $\left(\mathrm{P}_{\mathrm{cnt}}\right)$ saturating ingestion rate. Values of $m$ and $P_{c n i}$ giving any reasonable fit to Heinbokel's data (1978, Fig, 7) allowed the modelled microzooplankton to control phytoplankton stock continuously without a feeding threshold. For example, with $m=$ 0.0016 and $P_{\text {crt }}=25 \mathrm{mgC} \mathrm{m}^{-3}$, the predicted standing stock of phytoplankton, production rate of the phytoplankton, and concentration of herbivorous microzooplankton were virtually identical to those in Fig. 8.

Increasing and decreasing $\alpha$, the photosynthetic efficiency, caused peak herbivore standing stock and annual phytoplankton production to increase and decrease (Table 3). As long as phytoplankton growth 
was positive in winter, the herbivorous microzooplankton readily controlled the stock of phytoplankton, keeping it always below $0.5 \mathrm{mg} \mathrm{chl} \alpha \mathrm{m}^{-3}$, even if $\alpha$ was increased to 1.5 , which predicted annual phytoplankton production of $44.7 \mathrm{gC} \mathrm{m}^{-2}, 60 \%$ higher than that in Fig. 8. Systematically doubling the carbon-to-chlorophyll ratio, c, did not affect grazing control of phytoplankton stock, but resulted in very low predicted standing stocks and annual production of phytoplankton. Increasing $P_{0}$ or $g$ gave more realistic predictions when $c$ was doubled.

Positive net phytoplankton production in winter may be important to permit grazers to control phytoplankton stock during the following spring and summer (Evans \& Parslow 1985). With $\alpha$ decreased to 0.3, which resulted in negative net production of phytoplankton for about $30 \mathrm{~d}$ in winter, the microzooplankton were still able to control phytoplankton stock, though a small peak in chlorophyll a $\left(\sim 1.1 \mathrm{mg} \mathrm{m}^{-3}\right)$ occurred in spring (Day 130). However, because phytoplankton stock declined to an unnaturally low level $(\sim 0.11 \mathrm{mg}$ chl a $\mathrm{m}^{-3}$ ) for at least $30 \mathrm{~d}$ in winter, and annual phytoplankton production was only about $10 \mathrm{gC} \mathrm{m}^{-2}$, this does not appear to be a reasonable representation of the annual cycle at Station P. In the model the ability of microzooplankton to control phytoplankton stock in spring depended on the relative magnitudes of herbivore growth rate and mortality rate in winter. In the result in Fig. 8, with mortality rate of the herbivore density dependent (Eqn 19), herbivore growth rate was nil in early winter, but herbivore mortality rate was also very low $\left(\sim 0.02 \mathrm{~d}^{-1}\right)$, so herbivore stock declined very slowly. However, given phytoplankton growth as described in Fig. 4, when mortality rate was densityindependent (i.e. g was a constant), unnaturally high concentrations of phytoplankton $\left(>0.09 \mathrm{mg} \mathrm{chl} \mathrm{a} \mathrm{m} \mathrm{m}^{-3}\right)$ occurred in winter if $\mathrm{g}$ exceeded $0.05 \mathrm{~d}^{-1}$. Despite this, grazers continuously controlled the phytoplankton stock even with $g$ up to $0.1 \mathrm{~d}^{-1}$. In contrast, when $\alpha=$ 0.3 , a condition assuring negative net production of phytoplankton for about $30 \mathrm{~d}$ in winter, $\mathrm{g}$ had to be less than about $0.02 \mathrm{~d}^{-1}$ if temperature-independent (i.e. a constant), otherwise intense blooms of phytoplankton occurred in late spring. The mechanism is explained by Evans \& Parslow (1985). Thus, in this model continuous maintenance of phytoplankton stock at realistic concentrations by herbivores depended not only on the level of winter phytoplankton production but also on herbivore mortality rate in winter.

Vertical mixing in the model represented an added mortality for both phytoplankton and microzooplankton. Within limits, the predicted phytoplankton stock and production rate were relatively insensitive to changes in the mixing coefficient $v$. Thus with 5 -fold change in $v$, from 0.005 to 0.025 , annual phytoplankton production increased from 26.8 to $30.0 \mathrm{gC} \mathrm{m}^{-2}$. Similarly, predicted maximum stock of herbivorous microzooplankton declined less than $10 \%$ over the stated range of $v$, though predicted winter stock decreased substantially and in direct proportion to increasing $v$. Dilution of the phytoplankton after Day 260, simulating the effect of a deepening mixed layer, had a minor effect on model predictions. For example, annual phytoplankton production increased by $0.5 \%$; at Day 130 the concentration of chlorophyll $a$ and stock of herbivorous microzooplankton were identical to those in Fig. 8. Dilution is considered no further in this paper.

\section{Experiment 4 - role of mesozooplankton, especially Neocalanus spp.}

Given the plausibility of microzooplankton as potential major grazers of phytoplankton, what role would the very conspicuous, seasonally variable stock of mesozooplankton play in the plankton dynamics? The potential role of large suspension-feeding mesozooplankton (especially species of Neocalanus) was explored in the last elaboration of the model.

One possibility is a more complicated trophic interaction in which mesozooplankton feed indiscriminantly and equally efficiently on phytoplankton and herbivorous microzooplankton (Fig. 9). To evaluate this scheme ingestion rate of the mesozooplankton assemblage feeding on both phytoplankton and microzooplankton was represented as

$$
m g C m^{-3} d^{-1}=\frac{e^{\prime}(P+H)}{f^{\prime}+P+H} Z
$$

where $e^{\prime}$ and $\mathrm{f}^{\prime}=$ grazing parameters applicable to mesozooplankton; and $\mathrm{Z}=$ observed mean mesozooplankton stock (2 alternatives in Fig. 6). The phytoplankton fraction of total mesozooplankton ingestion is given by

$$
\frac{e^{\prime} P Z}{f^{\prime}+P+H}
$$

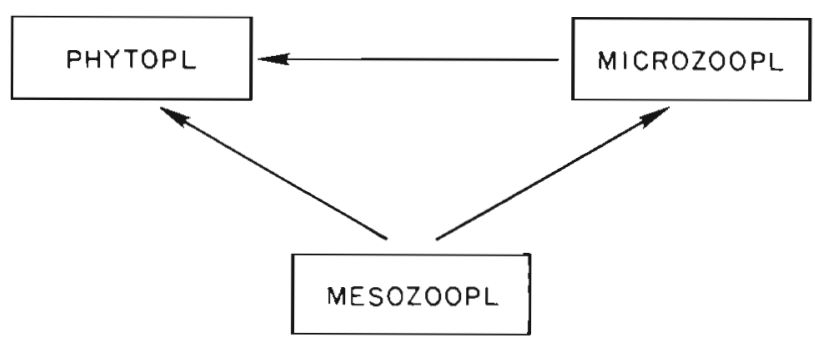

Fig. 9. A 3-compartment planktonic food web for open waters of the subarctic Pacific Ocean. Mesozooplankton are assumed to feed indiscriminantly and equally efficiently on phytoplankton and microzooplankton 
The model consisted of Eqns (13), (14) and (21) modified such that

$$
\begin{aligned}
\frac{\Delta \mathrm{P}}{\Delta \mathrm{t}} & =\frac{1}{\mathrm{z}_{\mathrm{m}}}\left\{\sum_{z=0}^{z_{m}} \mathrm{P} \cdot \mathrm{PMAX}^{\cdot} \tanh \left(\frac{\alpha \mathrm{PAR}_{\mathrm{z}}}{\mathrm{PMAX}^{\cdot}}\right) \frac{\mathrm{N}}{\mathrm{d}+\mathrm{N}}\right. \\
& -\mathrm{r}(\mathrm{PMAX}) \mathrm{P}\}-\mathrm{vP}-\frac{\mathrm{e}\left(\mathrm{P}-\mathrm{P}_{0}\right) \mathrm{H}}{\mathrm{f}+\left(\mathrm{P}-\mathrm{P}_{0}\right)}-\frac{\mathrm{e}^{\prime} \mathrm{P}}{\mathrm{f}^{\prime}+\mathrm{P}+\mathrm{H}} \mathrm{Z}
\end{aligned}
$$

$$
\begin{aligned}
\frac{\Delta N}{\Delta t}= & -\frac{1}{z_{m}}\left\{\sum_{z=0}^{z_{m}} P^{\bullet} P M A X \cdot \tanh \left(\frac{\alpha P A R_{z}}{P_{M A X}^{*}}\right) \frac{N}{d+N}\right\} \\
& +v\left(N_{0}-N\right)+\frac{0.3 e\left(P-P_{0}\right) H}{f+\left(P-P_{0}\right)}+\frac{0.3 e^{\prime}(P+H) Z}{f^{\prime}+P+H}
\end{aligned}
$$

$\frac{\Delta \mathrm{H}}{\Delta \mathrm{t}}=\mathrm{H}\left\{\frac{0.5 \mathrm{e}\left(\mathrm{P}-\mathrm{P}_{0}\right)}{\mathrm{f}+\left(\mathrm{P}-\mathrm{P}_{0}\right)}-\frac{\mathrm{e}^{\prime} \mathrm{Z}}{\mathrm{f}^{\prime}+\mathrm{P}+\mathrm{H}}-\mathrm{v}\right\}$

Parameter values for phytoplankton growth and microzooplankton growth and grazing were those used to produce Fig. 4A \& 8 (Table 1). The parameter values chosen for ingestion rate of mesozooplankton (Eqn 23) were based on results of feeding experiments with copepodid Stage $\mathrm{V}$ of Neocalanus plumchrus (Frost et al. 1983, Dagg \& Walser 1987, M. R. Landry pers.

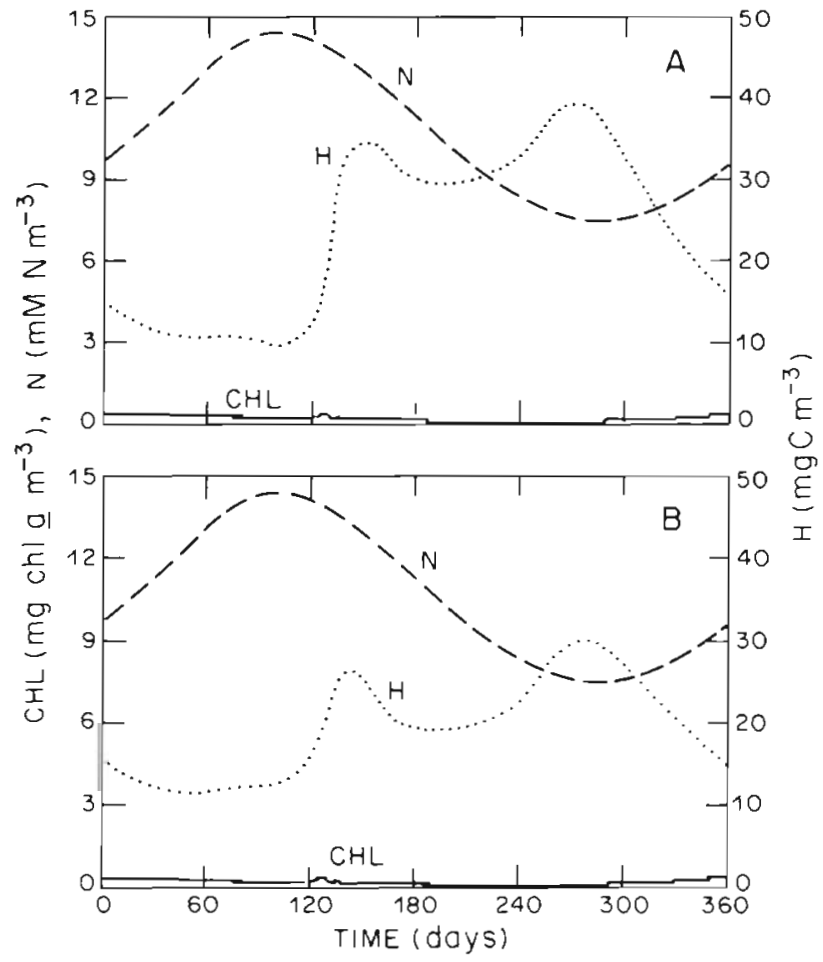

Fig. 10. Predicted annual cycles of phytoplankton standing stock (CHL), herbivorous microzooplankton (H), and nutrient concentration $(\mathrm{N})$ in the mixed layer, for the 3-compartment food web (Fig. 9). (A, B) Cases in which mesozooplankton stock followed patterns in Fig. 6A, B. Predicted annual phytoplankton production was 22.7 (A) and 24.5 (B) $\mathrm{gC} \mathrm{m}^{-2}$ comm.): $\mathrm{e}^{\prime}=0.123$ and $0.2 \mathrm{mgC} \mathrm{mgC}^{-1}$ at 5 and $12{ }^{\circ} \mathrm{C}_{i}$ $\mathrm{f}^{\prime}=50 \mathrm{mgC} \mathrm{m}^{-3}$. Strictly speaking, these values should apply only during winter to midsummer when $N$. plumchrus is a major component of the mesozooplankton (Miller et al. 1984); however, there is no experimental basis for using different parameter values at other times of the year.

The model predicted low standing stock of phytoplankton $\left(<0.35 \mathrm{mg} \mathrm{chl} \mathrm{a} \mathrm{m}^{-3}\right)$ throughout the year (Fig. 10). The predicted annual phytoplankton production rates were low, 22.7 to $24.5 \mathrm{gC} \mathrm{m}^{-2}$, but consistent with observations as were the predicted annual cycles of nitrate in the mixed layer. There was a marked seasonal cycle in predicted standing stock of microzooplankton, with maxima in spring and late summer/ early autumn. The decline in herbivorous microzooplankton in summer coincided with the period of high abundance of mesozooplankton (Fig. 6).

Given fixed values of parameters for mesozooplankton grazing, the magnitude of the predicted maximum stock of microzooplankton depended on maximum ingestion rate of herbivorous microzooplankton (e) and microzooplankton growth efficiency. As in the previous experiment, changes in these parameters caused changes in both abundance of microzooplankton and in predicted annual phytoplankton production (Table 4), but did not affect control of the phytoplankton stock by grazers. Similarly, given fixed values of parameters for microzooplankton grazing and growth, the maximum microzooplankton stock depended inversely on the maximum specific ingestion rate of the mesozoo-

Table 4 . Changes in predicted annual phytoplankton production (P) and maximum standing stock of herbivorous microzooplankton $(H)$ in autumn when a single parameter of the model (3-compartment food web, Fig. 9) was changed. + or -

\begin{tabular}{|c|c|c|c|c|}
\hline \multirow[t]{2}{*}{ Parameter } & \multirow[t]{2}{*}{ Value } & \multirow[t]{2}{*}{$\begin{array}{c}\mathrm{z} \\
\text { conc'd in }\end{array}$} & \multicolumn{2}{|c|}{$\begin{array}{l}\% \text { change relative } \\
\text { to values in Fig. } 10\end{array}$} \\
\hline & & & $\mathrm{H}$ & $\mathrm{P}$ \\
\hline e & $1.96-3.18(+)$ & $\begin{array}{l}\text { Upper } 50 \mathrm{~m} \\
\text { Mixed layer }\end{array}$ & $\begin{array}{l}-18.3 \\
-15.6\end{array}$ & $\begin{array}{l}-12.8 \\
-14.4\end{array}$ \\
\hline $\begin{array}{l}\text { Gross eff. of } \\
\text { microzoo. }\end{array}$ & $30 \%(-)$ & $\begin{array}{l}\text { Upper } 50 \mathrm{~m} \\
\text { Mixed layer }\end{array}$ & $\begin{array}{l}-36.8 \\
-33.8\end{array}$ & $\begin{array}{l}+24.0 \\
+25.2\end{array}$ \\
\hline $\mathrm{e}^{\prime}$ & $0.185-0.3011+$ & $\begin{array}{l}\text { Upper } 50 \mathrm{~m} \\
\text { Mixed layer }\end{array}$ & $\begin{array}{l}-22.0 \\
-22.6\end{array}$ & $\begin{array}{l}+10.2 \\
+14.2\end{array}$ \\
\hline$e^{\prime}$ & $0.246-0.4001+$ & $\begin{array}{l}\text { Upper } 50 \mathrm{~m} \\
\text { Mixed layer }\end{array}$ & $\begin{array}{l}-35.0 \\
-36.4\end{array}$ & $\begin{array}{l}+21.6 \\
+31.4\end{array}$ \\
\hline$\alpha$ & $1.0(+)$ & $\begin{array}{l}\text { Upper } 50 \mathrm{~m} \\
\text { Mixed layer }\end{array}$ & $\begin{array}{l}+31.7 \\
+31.7\end{array}$ & $\begin{array}{l}+19.0 \\
+18.9\end{array}$ \\
\hline
\end{tabular}
in parentheses indicate that parameter value was higher or lower than value in Fig. 10. Z: mesoplankton standing stock (Fig. 6) 
plankton (e'). With either pattern of Z (Fig. 6), the grazers maintained a relatively constant, low standing stock of phytoplankton $\left(<0.7 \mathrm{mg} \mathrm{chl} \mathrm{a} \mathrm{m}^{-3}\right)$ with $\mathrm{e}^{\prime}$ at $5^{\circ} \mathrm{C}$ increased to either 0.185 or 0.246 , that is, effectively doubling the coefficient of maximum predation mortality.

This last result raised the possibility that the model with a 3-compartment food web (Fig. 9) would give reasonable predictions even if mesozooplankton abundance was systematically lower or higher throughout a year. In fact, large interannual variations have occurred in standing stock of mesozooplankton at Station P. Annual average standing stock of mesozooplankton has deviated, in the extreme, by about $50 \%$ of the long-term mean (see Fig. 4 in Frost 1983). With either alternative for $Z$ (Fig. 5), increasing and decreasing $\mathrm{Z}$ by $50 \%$ did not alter the pattern of grazing control of phytoplankton stock (Fig. 11); predicted concentration of chlorophyll a never exceeded $0.45 \mathrm{mg}$ $\mathrm{m}^{-3}$. This indicates that over the natural range of interannual variation of mesozooplankton stock the interaction illustrated in Fig. 9 is resilient.

Control of phytoplankton stock was also unaffected by the level of phytoplankton production. If $\alpha$, the photosynthetic efficiency, was increased, predicted peak standing stock of herbivorous microzooplankton and annual phytoplankton production also increased

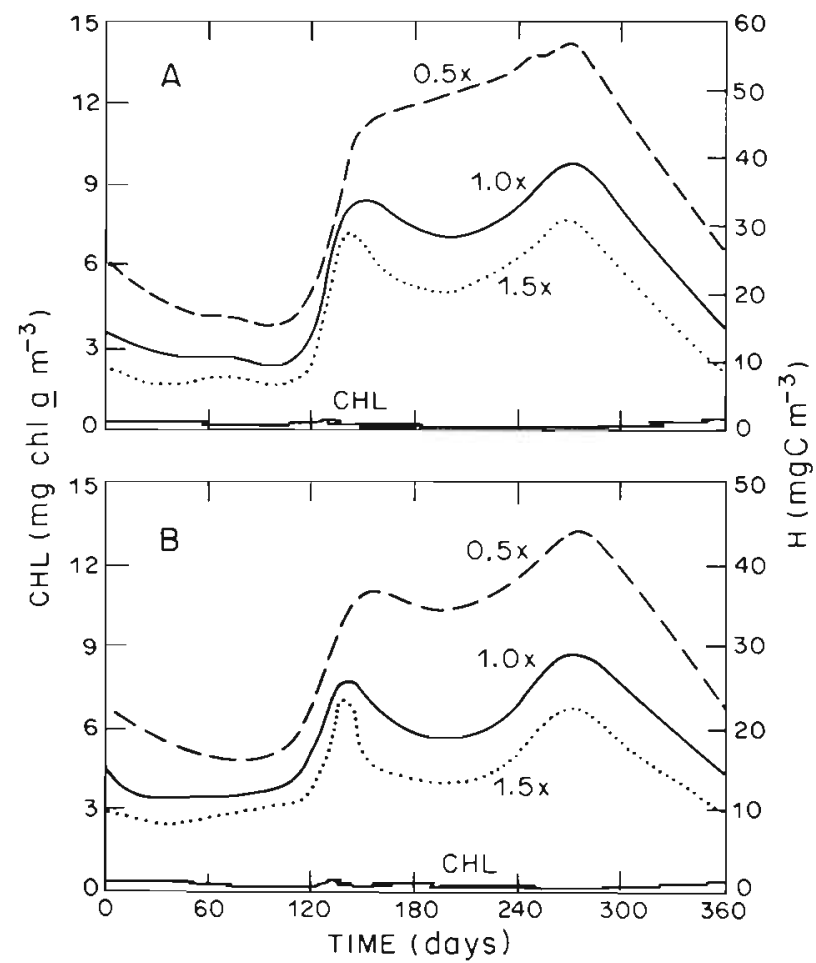

Fig. 11. As Fig. 10, but mesozooplankton standing stock ( $\mathrm{Z}$ in Fig. 6A, B) was increased and decreased by the factor indicated. For clarity, nutrient concentration was omitted
(Table 4). Even if $\alpha$ was 1.0 , giving nearly twice the annual phytoplankton production rates in Fig. 10, the grazers still kept the phytoplankton stock continuously below $0.4 \mathrm{mg} \mathrm{chl} \mathrm{a} \mathrm{m}{ }^{-3}$. With $\alpha=0.3$, which resulted in negative net production of phytoplankton for about a month in winter, grazing control of phytoplankton stock was still maintained throughout the year, although small peaks in chlorophyll a $(1.5$ to $3.0 \mathrm{mg}$ $\mathrm{m}^{-3}$ ) occurred in spring (both versions of $\mathrm{Z}$ ). Nevertheless, as in the previous experiment, this result is rejected as a representation of the annual cycle at Station P not only because of high predicted phytoplankton stocks in spring, but also because of unnaturally low concentrations of chlorophyll a $\left(<0.09 \mathrm{mg} \mathrm{m}^{-3}\right)$ in winter.

In the model, mesozooplankton always contributed less than $30 \%$ of the total grazing mortality of zooplankton (Fig. 12A). Even at their maximum concentration, on Day 170, mesozooplankton accounted for only 9 to $17 \%$ of the total grazing rate, despite their
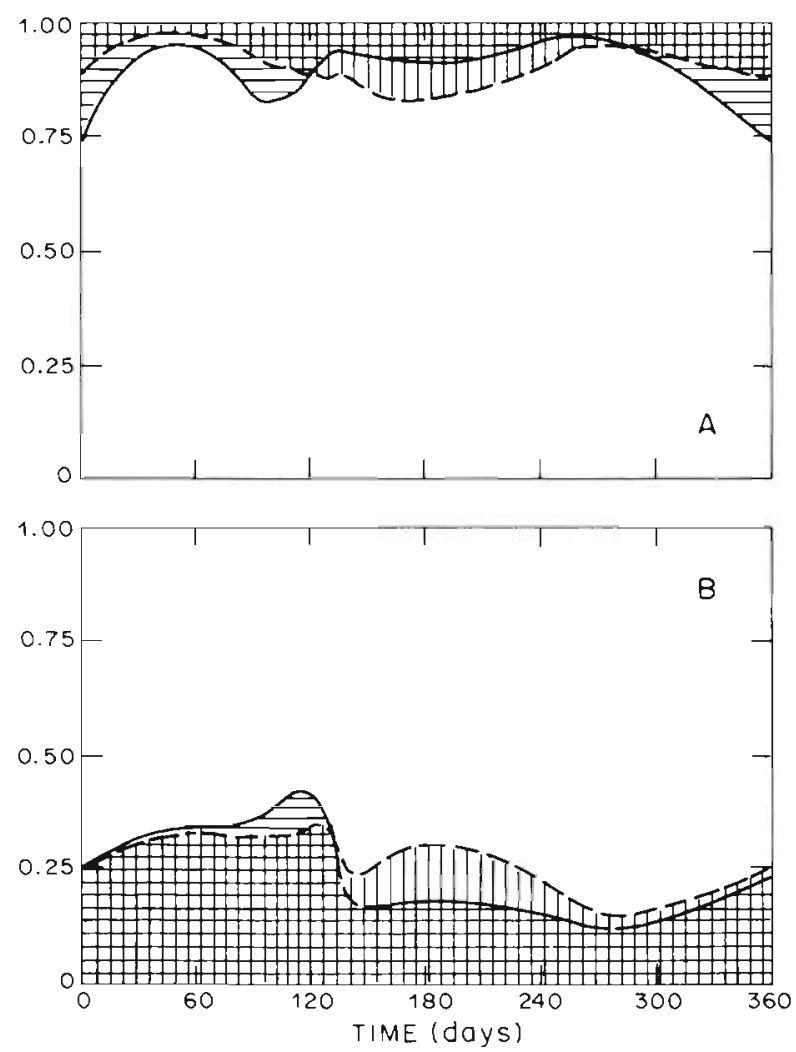

Fig. 12. Predictions from the model of the 3-compartment food web (Fig. 10). (A) Proportions of total phytoplankton grazing due to herbivorous microzooplankton (clear) and mesozooplankton (hatched). Solid curve and horizontal hatching: mesozooplankton concentrated in the upper $50 \mathrm{~m}$; dashed curve and vertical hatching: mesozooplankton aggregated in the mixed layer. (B) Proportions of total diet of mesozooplankton contributed by phytoplankton (hatched) and herbivorous microzooplankton (clear); curves and hatching as in A 
concentration being nearly as great (Fig. 10A) or twice as great (Fig. 10B) as the microzooplankton. This is not only a more complete and quantitative expression of the conclusions reached from Experiment 2, but indicates that if mesozooplankton do feed indiscriminantly on phytoplankton and herbivorous microzooplankton, they play a secondary role as grazers of phytoplankton. Nevertheless, phytoplankton may at times make up a significant fraction of the diet of mesozooplankton (Fig. 12B).

The realism of the grazing and predation rates attributed to the mesozooplankton can be evaluated by calculating expected growth rates and development times, assuming, for example, that the mesozooplankton is predominantly Neocalanus plumchrus, the bestknown mesoplanktonic species at Station P. For the calculation it is assumed that maximum assimilation rate $\left(A_{m}, \mu g C\right.$ ind $\left.^{-1} d^{-1}\right)$ is related to body mass $(W, \mu g C$ ind $^{-1}$ ) by the allometric equation:

$$
\mathrm{A}_{\mathrm{m}}=\mathrm{nW}^{0.8}
$$

Taking, from Fig. 10 and Table 4, a middle value of $0.2 \mu \mathrm{gC} \mu \mathrm{gC}^{-1} \mathrm{~d}^{-\mathrm{t}}$ for maximum specific ingestion rate (e') of copepodid Stage $V$ of $N$. plumchrus with body mass of $200 \mu \mathrm{gC}$, and assuming an assimilation efficiency of $80 \%$, then maximum assimilation rate is

$$
A_{m}=0.462 W^{0.8}
$$

For $N$. plumchrus feeding on both phytoplankton (P) and herbivorous microzooplankton $(\mathrm{H})$, growth rate at any concentration of prey is

$$
\frac{\mathrm{dW}}{\mathrm{dt}}=\left[\frac{\mathrm{n}(\mathrm{P}+\mathrm{H})}{\mathrm{f}^{\prime}+\mathrm{P}+\mathrm{H}}-\mathrm{q}\right] \mathrm{W}^{0.8}
$$

where $\mathrm{q}=$ the coefficient of daily mass-specific respiration. At $10^{\circ} \mathrm{C} \mathrm{N}$. plumchrus respire carbon equivalent to about $10 \%$ of their body carbon per day (Taguchi \& Ishii 1972, Vidal \& Whitledge 1982), giving $q=0.144$ for a copepodid Stage $V$ of $200 \mu \mathrm{gC}$. Taking from the model $\mathrm{f}^{\prime}=50$, and assuming constant values for $\mathrm{P}$ and $\mathrm{H}$ of 10 and $25 \mu \mathrm{gC} \mathrm{l}^{-1}$, about mid-range of winterspring concentrations in Fig. 10, growth rate at ambient prey concentrations is therefore

$$
\frac{\mathrm{dW}}{\mathrm{dt}}=0.046 \mathrm{~W}^{0.8}
$$

Noting that at Station P only copepodid Stages I to $\mathrm{V}$ of $N$. plumchrus inhabit the mixed layer (Miller et al. 1984), then integrating over the time interval $t_{d}$ required by $N$. plumchrus to develop from copepodid Stage I to copepodid Stage $V$ gives

$$
W_{V}=\left(W_{\mathrm{I}}^{0.2}+0.0092 t_{d}\right)^{5}
$$

where $W_{I}=$ mass of copepodid Stage $I_{i} W_{V}=$ mass of copepodid Stage V. Substituting $W_{\mathrm{I}}=7.8 \mu \mathrm{gC}$ (Parsons et al. 1969) and $W_{V}=200 \mu \mathrm{gC}$, the time required for development is about $150 \mathrm{~d}$.

The estimate of development time is, of course, highly sensitive to food concentrations and to the maximum ingestion rate $\left(e^{\prime}\right)$. If, for example, $P+H$ is increased by only $10 \mu \mathrm{gC}^{-1}$ the growth coefficient in the allometric equation increases from 0.046 to 0.075 , decreasing the estimated development time to about $92 \mathrm{~d}$. This could occur if phytoplankton production rate was slightly higher (Table 4). Similarly, increasing $\mathrm{e}^{\text {' }}$ from 0.2 to 0.25 decreases the estimated development time to about $73 \mathrm{~d}$. Nothing is known about development time of Neocalanus plumchrus at Station P. Copepodid stages are abundant in the mixed layer from March through early August (Miller et al. 1984), though development time cannot be inferred because of continuous recruitment. The calculated development times are somewhat longer than the $60 \mathrm{~d}$ period inferred from the progression of developmental stages of $N$. plumchrus in the Strait of Georgia (Parsons et al. 1969) and the eastern Bering Sea (Vidal \& Smith 1986). However, phytoplankton typically is much more abundant at these localities than at Station $\mathrm{P}$, and more rapid development would be expected.

Thus, while the ingestion rates of mesozooplankton used in the model (Fig. 10, Table 3) are low, they are realistic, that is, based on experimental observations, and would also permit at least one mesoplanktonic species to complete its growth and development in reasonable time at the ambient concentrations of its prey.

\section{DISCUSSION}

The postulated roles of micro- and mesozooplankton in the control of phytoplankton stock in the open subarctic Pacific hinge on the actual level of phytoplankton production and the reliability of estimates of mesozooplankton standing stock and its grazing capacity. Both deserve some additional comment.

Despite nearly 2 decades of observations at Station $P$, the annual cycle of phytoplankton production rate is not well established. Two analyses of the observations gave significantly different estimates of annual phytoplankton production (McAllister 1972, Parslow 1981). both of which are accomodated within the highly variable data (Fig. 4B). The model (Fig. 4A), which gave an annual production rate midway between those of McAllister (1972) and Parslow (1981), was considered to predict phytoplankton production rate conservatively, chiefly on the basis of more recent, independent, estimates of phytoplankton productivity at Station $P$ and other localities in the central subarctic Pacific. 
Should this turn out to be so, then conclusions about the mesozooplankton as minor grazers of phytoplankton are robust; that is, if phytoplankton production rate at Station $\mathrm{P}$ is actually higher than predicted in Fig. 4A, then mesozooplankton must graze at even higher rates than indicated in Fig. 7, an impossible condition. By contrast, with microzooplankton as major grazers of phytoplankton (Expts $3 \& 4$ ), the phytoplankton stock was easily controlled with any reasonably higher level of phytoplankton production than that in Fig. 4A. Control only became a problem if the net production rate of phytoplankton was negative in winter. The latter possibility will be discussed shortly.

Results of the model suggest that mesozooplankton as sampled at Station P cannot be solely responsible for control of phytoplankton stock. The mesozooplankton stock is not large enough, given observed feeding capabilities of the dominant species (Neocalanus spp.), to remove all daily phytoplankton production. This is evident in all of the previous models of phytoplankton production at Station $\mathrm{P}$ in which mesozooplankton grazing was explicitly included. In the model of Anderson et al. (1977) grazing was represented as a simple function of observed standing stock of mesozooplankton at Station P. Even with the standing stock of mesozooplankton increased 2.7 times, a maximum

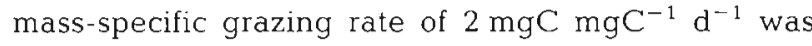
required to obtain a realistic annual cycle of phytoplankton standing stock and production rate. This maximum mass-specific grazing rate is about 10 times that observed for the species of Neocalanus (see Expt 4). Parslow's (1981) model employed a mass-specific ingestion rate that was only about 2 to 4 times the experimentally observed values for $N$. plumchrus (see Expt 4) and $N$. cristatus (Dagg \& Wyman 1983), but the model also predicted substantially lower phytoplankton production rates than that of Anderson et al. (1977) and the present model.

Mesozooplankton at Station $\mathrm{P}$ was sampled with relatively coarse-meshed nets $(\sim 350 \mu \mathrm{m})$ and a significant fraction of smaller mesozooplankton would have been missed. Moreover, the data of Miller et al. (1984) indicate that an assemblage of small zooplankton, those passing a 333 um mesh screen but retained on a $73 \mu \mathrm{m}$ mesh screen, exists at Station $\mathrm{P}$ in quantity equivalent to about half the standing stock retained by $333 \mu \mathrm{m}$ mesh. Given the size of these smaller mesoand microzooplankters, they could exert significant grazing pressure on the phytoplankton if they indeed consume phytoplankton. However, the stock is dominated ( $>80 \%$ of the mass) by small copepods of the genus Oithona (Miller et al. 1984) which are known to feed at rates disproportionately very low in relation to their small body size (Lampitt 1982, Drits \& Semenova 1984).
This leaves a deficit in the required grazing that can only be associated with heterotrophic organisms smaller than $73 \mu \mathrm{m}$. There is, unfortunately, little data on the annual cycle in numbers and types of likely microzooplankton grazers at Station P. The published data for Station P (LeBrasseur \& Kennedy 1972) suggest that microzooplankton are much too rare to be significant grazers of phytoplankton required by the model (Fig. 8 \& 10). However, the sampling methods were probably inadequate (e.g. microzooplankton collected on $44 \mu \mathrm{m}$ mesh screens) since a fraction of the smallest microzooplankton and any of the nanozooplankton (phagotrophs 0.002 to $0.02 \mathrm{~mm}$ in length) would not have been retained. Recent sampling in the open subarctic Pacific (Booth et al. 1982, B. C. Booth pers. comm.) revealed high cell concentrations of minute choanoflagellates and ciliates which would have passed through the screens used in the study by LeBrasseur \& Kennedy (1972). Perhaps these protists were responsible for much of the large unaccounted fraction of non-plant protein at Station $\mathrm{P}$ noted by Banse (1962). The concentrations of herbivorous microzooplankton predicted by the model (Fig. 8 \& 10) are still considerably less than the concentration of nonplant living carbon estimated at Station P by Banse (1962).

In Experiments 3 \& 4, the microzooplankter, modelled on a tintinnid ciliate, was a relatively large phagotrophic protozoan. It can be inferred from Tables $3 \& 4$ that the predicted standing stock of herbivorous microzooplankton would be considerably smaller if the protists were much smaller than tintinnids, thus having higher mass-specific ingestion rates than those used in Experiments $3 \& 4$, and if they had growth efficiencies less than $50 \%$. Both conditions are realistic possibilities.

Evans \& Parslow (1985) noted the importance of positive net production of phytoplankton in winter for control of phytoplankton stock by grazers in the following spring. The present model did not predict realistic standing stock of phytoplankton in winter if net production rate was negative in winter. This could mean either that phytoplankton production rate is indeed positive at Station $\mathrm{P}$ in winter, or that phytoplankton have other mechanisms, not represented in the model, for coping with severe light limitation in winter. Some type of metabolic adjustment, such as significantly lower respiration rate, is one possibility. Similarly, the dynamics of herbivorous microzooplankton were modelled (Expt 3) without explicit representation of metabolic rate. If a size-dependent metabolic rate was included in the description of growth rate of microzooplankton, and if the net production rate of phytoplankton was negative in winter, then balance between phytoplankton growth and microzooplankton grazing 
the following spring would not be possible. In effect, the model in its present form gives the microzooplankton zero metabolic rate when its ingestion rate is zero, approximating the spectacular down-shift of metabolic rate noted in starving protozoans (Fenchel \& Finlay 1983, Caron et al. 1985).

The postulated new role for mesozooplankton (Fig. 9), particularly the large calanoid copepods Neocalanus spp., resolves at least 4 problems. First, the model put broad, but specific, limits on the foraging capabilities of the mesozooplankton if they alone were to control the stock of phytoplankton, and experimental studies of feeding indicate that the Neocalanus species simply do not have the required capability. The discrepancy is especially glaring in the case of $N$. cristatus which often comprises a major fraction of the mesozooplankton at Station P (Miller et al, 1984). Frost et al. (1983) detected a tendency toward carnivory in $N$. cristatus and such a trophic role would be consistent with the model portrayed in Experiment 4; at the time of the spring peak in stock of herbivorous microzooplankton the mesozooplankton feeding indiscriminantly on phytoplankton and microzooplankton obtain 60 to $80 \%$ of their ingested food from the latter (Fig. 12B).

Second, Parslow (1981) and Frost (unpubl.) found that ecosystem models portraying Neocalanus cristatus and $N$. plumchrus as the sole grazers of phytoplankton were not at all robust if the models attempted to describe explicitly the annual life histories, including diapause, of the 2 species. A simulated annual cycle of phytoplankton stock and production resembling observations could be obtained, but only by delicately balancing recruitment patterns and predation mortality of the copepods. Outside a narrow range of combinations of copepod recruitment and mortality, the models predicted either an autumn phytoplankton bloom or failure of one or both species of Neocalanus to enter diapause. These models also, of course, became inoperative as descriptions of the annual cycle when it was established that both species of Neocalanus leave the mixed layer in late summer and autumn (Miller et al. 1984).

Third, a less pivotal grazing role for species of Neocalanus is consistent with the observation that their abundance in the mixed layer is much more variable, on small and large spatial and temporal scales, than phytoplankton stock (Barraclough et al. 1969, Parsons \& Anderson 1970, Mackas pers. comm.). The version of the model in Experiment 4 gives reasonable standing stocks and production of phytoplankton with a broad range of abundance of mesozooplankton (Fig. 11). By inference from these results, the stock of microzooplankton grazers, the presumed major controllers of phytoplankton stock, should also exhibit large interannual variations, exactly out of phase with the mesozooplankton.

Fourth, the postulated cause and effect relationship between life history patterns of the species of Neocalanus and control of phytoplankton stock has never been entirely satisfactory, else why has such a relationship not evolved in other subpolar oceans? Evans \& Parslow (1985) suggest that the life history patterns of Neocalanus spp. have evolved as a consequence, not a cause, of a reliably predictable standing stock of food in the surface layer, promoted by the unusually shallow permanent halocline in the subarctic Pacific. The protracted spawning periods of $N$. cristatus and N. plumchrus (Miller et al. 1984, C. B. Miller pers. comm.) are consistent with this interpretation; spawning is not concentrated in winter to assure recruitment to the surface layer in spring, but begins in summer for 2 of the 3 species.

The new role for species of Neocalanus does not necessarily mean that they, and other species of mesozooplankton, are not essential components of the plankton dynamics. Should the results of LeBrasseur \& Kennedy (1972) be confirmed, the hypothesized major grazers among the microzooplankton must be very small $(<44 \mu \mathrm{m})$. Given the dominance of phytoplankton by nanoplankton-sized cells, it is plausible that microzooplankton are the major grazers of phytoplankton and that their grazing impacts the entire phytoplankton assemblage. However, the microzooplankton may not be able to graze the very rare, largest phytoplankters at high rates (but see Smetacek 1981, Goldman \& Caron 1985). Larger grazers among the mesozooplankton could be important consumers of larger phytoplankters (e.g. Frost et al. 1983) and may keep the numbers of large cells severely depressed (Clemons \& Miller 1984). This role of mesozooplankton grazers was not included in the model because growth dynamics of large and small phytoplankters would have to be described and there is little information on the phytoplankton assemblage in the subarctic Pacific to support doing so at this time.

The roles for micro- and mesozooplankton as grazers of phytoplankton in the open subarctic Pacific constitute a hypothesis that is plausible in theory and testable in practice. With regard to the microzooplankton, we need to know the kinds, numbers, and feeding rates, and their seasonal variation. With regard to the mesozooplankton, we need to know if they feed indiscriminately on phytoplankton and microzooplankton, and their feeding rates on the latter. All of these are achievable with present technology. Finally, the results of the model imply that either net production rate of the phytoplankton is positive for most of the winter or that phytoplankton and herbivorous zooplankton make metabolic adjustments to tolerate periods of light and 
food limitation in winter. To amplify on the comment by Evans \& Parslow (1985), the winter ecology of both trophic groups needs to be studied.

Acknowledgements. This began as part of a cooperative research project (with C. B. Miller) supported by Oregon Sea Grant through NOAA Office of Sea Grant 104-7-158-44085, Project No. R/OPF-9). Subsequently the research was supported by NSF grant OCE-7918687, and since 1985 has been a component of the multidisciplinary SUPER (Subarctic Pacific Ecosystem Research) program supported by NSF grants OCE-8414967 and OCE-8613621. I thank C. B. Miller both for his long, patient collaboration and for his thoughtful criticism of this work. Constructive critical comments were also received from K. Banse, G. T. Evans, J. S. Parslow, and T. R. Parsons; although they did not necessarily agree with my conclusions, they all read this work with a spirit of scientific inquiry, and for that I am grateful. J. Fulton provided the data on abundance of mesozooplankton at Station $\mathrm{P}$, and my colleagues in the SUPER program have been liberal with their ideas, observations, and data reports. Contribution No. 1700 from the School of Oceanography, University of Washington.

\section{LITERATURE CITED}

Andersen, V (1985). Filtration and ingestion rates of Salpa fusiformis Cuvier (Tunicata: Thaliacea): effects of size, individual weight and algal concentration. J. exp. mar. Biol. Ecol. 87: 13-29

Anderson, G. C., Munson, R. E. (1972). Primary productivity studies using merchant vessels in the North Pacific Ocean. In: Takenouti, A. Y (ed.) Biological oceanography of the northern North Pacific Ocean. Idemitsu Shoten, Tokyo, p. $245-251$

Anderson, G. C., Lam, R. K., Booth, B. C., Glass, J. M. (1977). A description and numerical analysis of the factors affecting the processes of production in the Gulf of Alaska. Univ. Washington, Dept. Oceanogr., Spec. Rep., p. 1-231

Anderson, G. C., Parsons, T R., Stephens, K. (1969). Nitrate distribution in the subarctic northeast Pacific Ocean. Deep Sea Res. 16: 329-334

Bannister, T. T. (1974). A general theory of steady state phytoplankton growth in a nutrient saturated mixed layer. Limnol. Oceanogr. 19: 13-30

Banse, K. (1962). Net zooplankton and total zooplankton. Rapp. P.-v. Réun. Cons. perm. int. Explor. Mer 153: 211-214

Barraclough, W. E., LeBrasseur, R. J., Kennedy, O. D. (1969). Shallow scattering layer in the subarctic Pacific Ocean: detection by high-frequency echo sounder. Science 166: 611-613

Beklemishev, K. V. (1957). The spatial relationships of marine zoo- and phytoplankton. Trudy Instituta okeanologii. Akademiya nauk SSSR 10: 253-278. (Translation: Nikitin, B. N. [ed.] 1959). Am. Inst. Biol. Sci., Washington, D. C., p. 206-226)

Booth, B. C. (in press). Vertical and temporal variation of phytoplankton from the subarctic Pacific, Station P. I. Size classes and major taxonomic groups. Mar. Biol.

Booth, B. C., Lewin, J., Norris, R. E. (1982). Nanoplankton species predominant in the subarctic Pacific in May and June 1978. Deep Sea Res. 29: 185-200

Brock, T. D. (1981). Calculating solar radiation for ecological studies. Ecol. Modelling 14: 1-19

Capriulo, G. M. (1982). Feeding of field collected tintinnid microzooplankton on natural food. Mar. Biol. 71: 73-86
Caron, D. A., Goldman, J. C., Andersen. O. K., Dennett, M. R. (1985). Nutrient cycling in a microflagellate food chain: II. Population dynamics and carbon cycling. Mar Ecol. Prog. Ser. 24: 243-254

Clemons, M. J., Miller, C. B. (1984). Blooms of large diatoms in the oceanic, subarctic Pacific. Deep Sea Res. 31: 85-95

Dagg, M. J., Vidal, J., Whitledge, T. E., Iverson, R. L., Goering, R. L. (1982). The feeding, respiration and excretion of zooplankton in the Bering Sea during a spring bloom. Deep Sea Res. 29: 45-63

Dagg, M. J., Walser, E. W., Jr. (1987). Ingestion, gut passage, and egestion by the copepod Neocalanus plumchrus in the laboratory and in the subarctic Pacific Ocean. Limnol. Oceanogr. 32: 178-188

Dagg, M. J., Wyman, K. D. (1983). Natural ingestion rates of the copepods Neocalanus plumchrus and $N$. cristatus calculated from gut contents. Mar. Ecol. Prog Ser 13: 37-46

Davis, R. E., de Szoeke, R., Halpern, D., Niiler, P. (1981). Variability in the upper ocean during MILE. Part I: The heat and momentum balances. Deep Sea Res. 28: $1427-1451$

Dodimead, A. J., Favorite, F., Hirano, T. (1963). Review of the oceanography of the subarctic Pacific region. Int. N. Pacific Fish. Comm. Bull. 13: 1-195

Drits, A. V., Semenova, T. N. (1984). Experimental investigations of the feeding of Oithona similis Claus. Oceanology 24: 755-759

Eppley, R. W. (1972). Temperature and phytoplankton growth in the sea. Fish. Bull. U. S. 70: 1063-1085

Evans, G. T., Parslow, J. S. (1985). A model of annual plankton cycles. Biol. Oceanogr. 3: 327-347

Fasham, M. J. R., Holligan, P. M., Pugh, P. R. (1983). The spatial and temporal development of the spring phytoplankton bloom in the Celtic Sea, April 1979. Prog. Oceanogr. 12: 87-145

Fenchel, T., Finlay, B. S. (1983). Respiration rates in heterotrophic, free-living Protozoa. Microb. Ecol. 9: 99-122

Frost, B. W (1983). Interannual variation of zooplankton standing stock in the open Gulf of Alaska. In: Wooster, W. S. (ed.) From year to year: interannual variability of the environment and fisheries of the Gulf of Alaska and eastern Bering Sea. Washington Sea Grant Publ., Univ. of Washington, p. 146-157

Frost, B. W., Landry, M. R., Hassett, R. P. (1983). Feeding behavior of large calanoid copepods Neocalanus cristatus and $N$. plumchrus from the subarctic Pacific Ocean. Deep Sea Res. 30: 1-13

Fulton, J. D. (1983). Seasonal and annual variations of net zooplankton at Ocean Station P, 1956-1980. Can. Data Rep. Fish. Aquat. Sci., No. 374

Goldman, J. C., Caron, D. A. (1985). Experimental studies on an omnivorous microflagellate: implications for grazing and nutrient regeneration in the marine microbial food chain. Deep Sea Res. 32: 899-915

Heinbokel, J. F. (1978). Studies on the functional role of tintinnids in the Southern California Bight. I. Grazing and growth rates in laboratory cultures. Mar. Biol. 47: 177-189

Heinrich, A. K. (1957). The breeding and development of the dominant copepods in the Bering Sea. Trudy vses. gidrobiol. Obshch. 8: 143-162 (Russian)

Heinrich, A. K. (1962). The life histories of plankton animals and seasonal cycles of plankton communities in the oceans. J. Cons. int. Explor. Mer 24: 455-464

Huntley, M., Boyd, C. (1984). Food-limited growth of marine zooplankton. Am. Nat. 124: 455-478

Jassby, A. D., Platt, T. (1976). Mathematical formulation of the 
relationship between photosynthesis and light for phytoplankton. Limnol. Oceanogr. 21: 540-547

Lampitt, R. S. (1982). Diet and respiration of the small planktonic copepod Oithona nana. Mar. Biol. 66: 185-190

Larrance, J. D. (1971). Primary production in the mid-subarctic Pacific region, 1966-68. Fish. Bull. U. S. 69: 595-613

LeBrasseur, R. J., Kennedy, O. D. (1972). Microzooplankton in coastal and oceanic areas of the Pacific subarctic water mass: a preliminary report. In: Takenouti, A. Y. (ed.) Biological oceanography of the northern North Pacific Ocean. Idemitsu Shoten, Tokyo, p. 355-365

McAllister, C. D. (1961). Zooplankton studies at Ocean Station ' $\mathrm{P}$ ' in the Northeast Pacific Ocean. J. Fish. Res. Bd Can. 18 $1-29$

McAllister, C. D. (1962). Data record. Photosynthesis and chlorophyll a measurements at ocean weather station ' $P$ ', July 1959 to November 1961. Fish. Res. Bd Can. Ms Rep. Ser. (Oceanogr, Limnol.) No. 126

McAllister, C. D. (1969). Aspects of estimating zooplankton production from phytoplankton production. J. Fish. Res. Bd Can. 26: 199-220

McAllister, C. D. (1970). Zooplankton rations, phytoplankton mortality and the estimation of marine production. In: Steele, J. H. (ed.) Marine food chains. Univ. California Press, Berkeley, p. 419-457

McAllister, C. D. (1972). Estimates of the transfer of primary production to secondary production at ocean station P. In Takenouti, A. Y. (ed.) Biological oceanography of the northern North Pacific Ocean. Idemitsu Shoten, Tokyo, p. 575-579

McAllister, C. D., Parsons, T. R., Strickland, J. D. H. (1960) Primary productivity and fertility at station ' $\mathrm{P}$ ' in the northeast Pacific Ocean. J. Cons. int. Explor. Mer 25: 240-259

Marlowe, C. J., Miller, C. B. (1975). Patterns of vertical distribution and vertical migration of zooplankton at Ocean Station P. Limnol. Oceanogr. 20: 824-844

Miller, C. B., Frost, B. W., Batchelder, H. P., Clemons, M. J., Conway, R. E. (1984). Life histories of large, grazing copepods in a subarctic ocean gyre: Neocalanus plumchrus, Neocalanus cristatus, and Eucalanus bungii in the Northeast Pacific. Prog. Oceanogr. 13: 201-243

Parslow, J. S. (1981). Phytoplankton-zooplankton interactions: data analysis and modelling (with particular reference to Ocean Station $\mathrm{P}\left[50^{\circ} \mathrm{N}, 145^{\circ} \mathrm{W}\right]$ and controlled ecosystem experiments). Ph. D. thesis, Univ. British Columbia

Parsons, T. R. (1965). A general description of some factors affecting primary production in the Strait of Georgia, Hecate Strait and Queen Charlotte Sound, and the N. E. Pacific Ocean. Fish. Res. Bd Can. Ms Rep. Ser. (Oceanogr. Limnol.) No. 193

Parsons, T R., Anderson, G. C. (1970). Large scale indices of primary production in the North Pacific Ocean. Deep Sea Res. 17: 765-776

Parsons, T. R., LeBrasseur, R. J. (1968). A discussion of some critical indices of primary and secondary production for large scale ocean surveys. Calif. Mar Res. Comm., CalCOFI Rep. 12: 54-63

Parsons, T R., LeBrasseur, R. J., Fulton, J. D., Kennedy, O. D. (1969). Production studies in the Strait of Georgia. Part II. Secondary production under the Fraser River plume, February to May 1967. J. exp. mar. Biol. Ecol. 3: 39-50

Parsons, T. R., Geovando, L. F., LeBrasseur, R. J. (1966). The advent of the spring bloom in the eastern subarctic Pacific Ocean. J. Fish. Res. Bd Can. 23: 539-546
Parsons, T. R., Takahashi, M., Hargrave, B. (1984). Biological oceanographic processes, 3rd edn. Pergamon Press, New York

Platt, T., Mann, K. H., Ulanowicz, R. E. (1981). Mathematical models in biological oceanography. UNESCO Monogr Oceanogr Methodol. 7

Platt, T., Lewis, M., Geider, R. (1984). Thermodynamics of the pelagic ecosystem: elementary closure calculations for biological production in the open ocean. In: Fasham, M. S. R. (ed.), Flows of energy and materials in marine ecosystems. Plenum Press, New York, p. 49-84

Riley, G. A. (1963). Theory of food-chain relations in the ocean. In: Hill, M. N. (ed.) The sea, Vol. 2. Interscience, New York, p. 438-463

Saino, T., Miyata, K., Hattori, A. (1979). Primary productivity in the Bering and Chukchi Seas and in the northern North Pacific in 1978 summer. Bull. Planktonol. Soc. Japan 26: 96-103

Sieburth, J. M., Smetacek, V., Lenz, J. (1978). Pelagic ecosystem structure: heterotrophic compartments of the plankton and their relationship to plankton size fractions. Limnol. Oceanogr. 23: 1256-1263

Smetacek, V. (1981). The annual cycle of protozooplankton in the Kiel Bight. Mar. Biol. 63: 1-11

Steele, J. H. (1974). The structure of marine ecosystems. Harvard Univ. Press, Cambridge

Steele, J. H., Frost, B. (1977). The structure of plankton communities. Phil. Trans. R. Soc. (B) 280: 485-534

Steemann Nielsen, E. (1974). Marine photosynthesis: with special emphasis on the ecological aspects. Elsevier Scientific, New York

Stephens, K. (1964). Data record. Productivity measurements in the northeast Pacific with associated chemical and physical data, 1958-1964. Fish. Res. Bd Can. MS Rep. Ser. (Oceanogr. Limnol.) No. 179

Stephens, K. (1966). Data record. Primary production data from the N. E. Pacific Ocean, January 1964 to December 1965. Fish. Res. Bd Can. MS Rep. Ser. (Oceanogr. Limnol.) No. 209

Stephens, K. (1968). Data record. Primary production data from the Northeast Pacific Ocean, January 1966 to December 1967. Fish. Res. Bd Can. MS Rep. Ser. (Oceanogr. Limnol.) No. 957

Taguchi, S., Ishii, H. (1972). Shipboard experiments on respiration, excretion, and grazing of Calanus cristatus and $C$. plumchrus (Copepoda) in the northern North Pacific. In: Takenouti, A. Y. (ed.) Biological oceanography of the northern North Pacific Ocean. Idemitsu Shoten, Tokyo, p. 419-431

Takahashi, M., Satake, K., Nakamoto, N. (1972). Chlorophyll distribution and phtoosynthetic activity in the North and Equatorial Pacific ocean along $155^{\circ} \mathrm{W}$. J. oceanogr. Soc. Japan 28: 27-34

Verity, P. G. (1985). Grazing, respiration, excretion, and growth rates of tintinnids. Limnol. Oceanogr 30 $1268-1282$

Vidal, J. Whitledge, T. E. (1982). Rates of metabolism of planktonic crustaceans as related to body weight and temperature of habitat. J. Plankton Res. 4: 77-84

Vidal, J., Smith, S. L. (1986). Biomass, growth, and development of populations of herbivorous zooplankton in the southeastern Bering Sea during spring. Deep Sea Res. 33: $523-556$ 